\title{
Efficiency Evaluation of BRICS's National Innovation Systems based on Bias-corrected Network Data Envelopment Analysis
}

Ibrahim Alnafrah ( $\square$ ibrahimalnafrah@gmail.com )

Damascus University

Research

Keywords: National innovation system, BRICS economies, Data Envelopment Analysis, DEA network, Knowledge commercialization, system failures

Posted Date: November 4th, 2020

DOI: https://doi.org/10.21203/rs.3.rs-100935/v1

License: (1) (1) This work is licensed under a Creative Commons Attribution 4.0 International License.

Read Full License

Version of Record: A version of this preprint was published at Journal of Innovation and Entrepreneurship on July 12th, 2021. See the published version at https://doi.org/10.1186/s13731-021-00159-3. 
Efficiency Evaluation of BRICS's National Innovation Systems based on Bias-corrected Network Data

\title{
Envelopment Analysis
}

\author{
Ibrahim Alnafrah $\underline{\text { ORCID } *}$
}

*Corresponding author: Ibrahim Alnafrah. Faculty of Economics, Damascus University, Damascus, Syria.

E-mail: ibrahimnafrah@gmail.com

Damascus, Syria, Tel: +963-982368404 


\begin{abstract}
The very limited studies that tried to measure the efficiency of national innovation systems (NISs) in BRICS economies were limited to the assumption that the innovation process at national level consists of one stage only and got different and conflicting results. Therefore, this study endeavours to measure the efficiency of subprocesses within the BRICS's NISs and identify where the system failure lies in each NIS.
\end{abstract}

Bias-corrected network data envelopment analysis (DEA) is used to measure the efficiency of total NIS and the efficiency of the other sub-processes within the system: (1) Knowledge Production Process (KPP), and (2) Knowledge Commercialization Process (KCP).

The results showed that NISs in BRICS economies suffer from low performance in commercializing their outputs of universities and research organizations. While, on the other hand, their performance in creating scientific and technical knowledge is good in comparison to other studied countries. We suggest that the reason behind this imbalance is the network system failure associated with weak institutions and high uncertainty in the economy.

In this study, we argue that the problem in BRICS NISs is not a problem of resources, but it is a problem of system management and institutions.

Some bridging policies are suggested to be adopted by BRICS economies to improve their innovation performance and overcome the system failure of weak links between universities and industry.

Keywords: National innovation system, BRICS economies, Data Envelopment Analysis, DEA network, Knowledge commercialization, system failures.

\title{
1. Introduction
}

Building a globally competitive economy today requires an economy with a high intensity of innovation activities at the national level. This innovativeness is a decisive factor that determines the potential of economic expansion and development of any economy since the economies of scale and low labour wages are no longer as decisive as they were two decades ago. Especially in emerging economies like BRICS economies. Therefore, there is a need for building an efficient national innovation system (NIS) in these countries in order to improve their economic competitiveness and sustainable economic growth based on innovation-related sources. 
As a result of a highly competitive global environment, policymakers need to ensure that their innovation policies and strategies are sound and oriented precisely toward overcoming the weakness and shortcomings of their NIS. This process requires a profound analysis of NIS and all its actors, their relationships and the structural patterns of its progress overtime (Castellacci and Natera 2013).

The notion of national innovation system as a systematic framework for studying creation, dissemination, and exchanging of knowledge and technologies at the national level was firstly introduced by (Freeman 1982; Freeman and Lundvall 1988). This concept has been developed since that time to include all institutions, organizations, and actors engaged in the innovation-related activities at sectoral, regional and national levels (Edquist 2009; Nelson 1993). The procedural objective of this conceptual framework is to study the relationships between the main actors within NIS and the needed mechanisms to develop these relationships to be more productive and efficient.

Existing literature that has studied NISs in developing economies such as BRICS economies was limited to four types of studies: (1) historical and theoretical analysis of NISs in BRICS countries (Cassiolato and Vitorino 2009; Scerri et al. 2010; Zaichenko n.d.), (2) studying the causal relationship between NIS's variables and their impact on the economic development (I. Alnafrah et al. 2018; Bogdanova and Alnafrah 2018; Rao-Nicholson et al. 2017), (3) using machine learning techniques to identify the structural strengths and weaknesses of NISs (Ibrahim Alnafrah 2019; Ibrahim Alnafrah and Zeno 2019), and (4) measuring the efficiency of specific innovation industries or sub-systems such as energy (Song et al. 2013; Tu et al. 2016), the insurance industry (Huang and Eling 2013), and ICT sector (Biryukova and Matiukhina 2019).

However, previous studies did not answer the following question: do the NISs in these economies work efficiently? The very limited studies that tried to measure the efficiency of NISs in BRICS economies based on conducting the Data Envelopment Analysis (DEA) were limited to the assumption that the innovation process at national level consists of one stage only (Cai and Hanley 2012; X. Liu and White 2001; Viotti 2002). These studies treated NIS as one unit, neglecting the fact that the efficiency score of the total system does not demonstrate the sub-systems' efficiencies scores (Cron and Sobol 1983; Kao and Hwang 2008, 2010; Li et al. 2016; C. H. Wang et al. 1997).

Therefore, this study tries to answer the following questions: (1) Do the NISs in BRICS countries work efficiently? (2) What types of inefficiencies do these systems suffer from?

Drawing on the work of (Carayannis et al. 2015; Cook et al. 2010; Guan and Chen 2012; Li et al. 2016), we assume in this study that the innovation process at the national level consists of two main processes: (1) 
Knowledge Production Process (KPP) and (2) Knowledge Commercialization Process (KCP), where these two processes cover all functions of the NIS's actors: universities, business sector, and government.

Accordingly, this study aims at measuring the efficiency of BRICS's NISs of two innovation-related processes and identifying where the system failure lies in each NIS.

This study endeavours to fill this research gap by conducting the Data Envelopment Analysis (DEA) to provide the policymakers with profound insights about the structural functioning of their NISs. Moreover, this study provides the answer to the following question: are the BRICS's NISs working efficiently or not, and if they are not, what kind of system failure they suffer from and in which process?

This study is structured as follows. First, we revise the literature of NIS's efficiency studies in developing economies, in addition to those that have been conducted in BRICS economies. Second, we illustrate the data and methodology used in this study. Third, we present and discuss the results. Finally, we draw our conclusion and provide some recommendations.

\section{Literature review}

The development of economic activities as a result of utilizing the outputs of digital and technological revolution has led to increasing the intensity of innovations at micro, meso and macroeconomic levels. This kind of progress included radical changes in the productivity and the mechanisms of innovation creation and diffusion, which in its turn led policymakers to devise theoretical and practical frameworks to measure the impact of innovation activities on the national economic performance. In other words, there was a need to find a new analysis framework to help policymakers explain the way in which new innovations and technologies emerge and diffuse at the national level and how these technologies and innovations influence the overall socio-economic performance.

These conditions have led to the emergence of the NIS as a systemic framework for analysing the economic performance associated with innovative activities, creating, disseminating and exchanging high technologies (Freeman 1982; Freeman and Lundvall 1988; Godin 2009; Lundvall 2007). This analysis framework is used to study the relationships among the main actors within NIS and the needed mechanisms to develop these relationships and make them more productive and efficient. Accordingly, the concept of the NIS is an important conceptual framework in the context of studying and analysing the emergence and diffusion of new technologies and innovations at the national level (Metcalfe and Ramlogan 2008). 
That being said, the NIS concept has been witnessed three main shifts: (1) shift towards macro structures of NIS and the interactions between the main actors within the system (K. Chen and Guan 2011), (2) shift towards technology, sectoral and regional innovation systems with special focus on the developing economies (Andersen et al. 2014; Malerba 2002), (3) growing emphasis on the internationalisation of NISs and the role of multinational corporations (MNCs) as a channel for global knowledge and innovation practices flows (Chung 2002; Distefano et al. 2016; Watkins et al. 2015). These shifts paved the way for studying the NISs in developing economies, and especially those that have achieved and maintained high and extensive economic growth rates over a decade.

Regarding the NISs in BRICS economies, they were included gradually in the NIS literature because of two main reasons: (1) BRICS economies had not built yet mature NISs (Kravtsova and Radosevic 2012), where their innovation activities were focused on specific sub-innovation processes in specific regions or industries (Watkins et al. 2015), (2) the economic openness and the development inclusion, that imposed the priority of building a national innovation network (Scerri, M., \& Lastres 2013).

In this context and since the economic and social development of countries depends on a country's capacity to create, disseminate and apply new knowledge and technologies (Metcalfe and Ramlogan 2008; Yao et al. 2009), it was important to ensure that NIS's functions and processes work efficiently. In doing so, several studies tried to measure the efficiency of NISs and other types of innovation systems (regional, sectoral and technology systems) in different countries, BRICS economies are included, to assess the role of these systems in the sustainability of economic growth (Afzal 2014; Matei and Aldea 2012; Samara et al. 2012; Tseng 2009). Moreover, the efficiency measurement studies of innovation systems were oriented towards analysing the dynamic progress of these systems over time, in addition to identifying the system failures associated with low-efficiency levels (C.-P. Chen et al. 2011; Guan and Chen 2012).

Applying DEA approach is one of the most widespread methods of measuring the innovation system performance. Building on the work of (Emrouznejad and Yang 2018), between 1980 and 2019, more than 4200 DEA related articles were published in the Scopus database. This growing tendency indicates the importance and implication benefits that DEA provides in the field of efficiency measurement studies. In this paper, we are interested in the innovation system related studies since our aim is to measure and analyse the efficiency of the NISs in BRICS countries.

Innovation system is a multilevel concept (Carayannis et al. 2016), where national, regional and sectoral innovation system can coexist and coevolve together in the same country. Accordingly, the existing literature of measuring the efficiency of innovation systems is divided into three categories. First, studies that measure the 
efficiency of the NIS (NIS) (Abbasi et al. 2011; Guan and Chen 2012; Sharma and Thomas 2008; E. C. Wang and Huang 2007). Second, studies that measure the efficiency of the regional innovation system (RIS) (K. Chen and Guan 2012; Didenko et al. 2017; Guan and Chen 2010; Lengyel and Leydesdorff 2011; Zabala-Iturriagagoitia et al. 2007). Third, studies that measure the efficiency of the sectoral innovation system (SIS) (Andersen et al. 2014; Z. Liu et al. 2018; Meng et al. 2006).

Regarding the efficiency analysis of NIS, there are several DEA-related articles in the existing literature. However, the most widespread studies are focused on developed economies such as EU and OECD (Hudec and Prochádzková 2013; Kou et al. 2016; Matei and Aldea 2012; Rousseau and Rousseau 1997; Tarnawska and Mavroeidis 2015).

However, most of previous studies that tried to evaluate the efficiency of NIS treated it as a one decision unit, which does not provide any insights to the policymakers (Grupp and Schubert 2010; Jiménez-Sáez et al. 2011; Lee and Park 2005; Namazi and Mohammadi 2018; Pan et al. 2010; Ramanathan et al. 2018; S. Wang et al. 2016; Zabala-Iturriagagoitia et al. 2007), leaving them with just an idea that their NIS works or does not work efficiently. Even this piece of information is not accurate enough to build on it any policy. In other words, the implication value of this kind of analysis is very low. What we are essentially arguing in this article is that measuring the efficiency of NIS should consider not only the overall innovation process but also all other sub-processes involved in this system.

Given the limitations of the previous DEA approaches, some studies applied additional econometric analyses such as Tobit regression (Afzal 2014; Matei and Aldea 2012) to investigate the impact of the environmental factors on the innovation performance, and super efficiency (K. Chen and Guan 2012; Pan et al. 2010) to generate a corrected ranking system. However, these additional econometric analyses do not help in demonstrating the relationship and interactions of the innovation processes within the NIS. Therefore, network DEA approach was applied to analyse the interaction between sub-innovation processes within the NIS (Carayannis et al. 2015).

Accordingly and in line with the existing literature (Carayannis et al. 2016; K. Chen et al. 2018; K. Chen and Guan 2012; Kou et al. 2016; Liou 2009), we propose using DEA network by splitting the overall national innovation process into two sub-processes: Knowledge Production Process (KPP), and Knowledge Commercialization Process (KCP). By doing so, policymakers will be able to get some insights about the overall performance of their NIS in addition to the performance of other sub-processes, which in its turn will help them 
in identifying what kind of system failure they are dealing with and how the allocation of sources could be made better.

Interestingly, when it comes to the efficiency measurement of BRICS's NISs, the literature is very limited and cases study oriented. There are only three studies that have measured the efficiency of NISs in these countries together. (Cai 2011) has studied the NISs of 22 countries including BRICS and G7. The findings of this study showed that BRICS's NISs have low performance in terms of their governance, in addition to a high dependency on natural resources. Cai argued that extensive economic growth does not enhance the competitiveness of BRICS economies. Therefore, he suggested transferring BRICS's factor-driven growth patterns into innovation-driven growth patterns. It is worth mentioning here that the absence of bias test for the efficiency results in this study led the author to inconsistent conclusions, for example, the negative relationship between the proxy variables of education system and the efficiency level of NIS. (Cai and Hanley 2012) have studied BRICS's NISs by conducting two-stages DEA method. They found that technological similarity is not the only criterion underpinning innovative performance. They argued that the socio-economic conditions also play a role in determining the innovativeness of country. The findings of this study showed that China, India, and Russia demonstrate relatively high-efficiency scores, whereas both Brazil and South Africa perform badly. Authors linked the "bad" performance of Brazil and South Africa with their strongly performing natural resources sector. In this context, it should be said that if that so, how the findings of this study explain the high-efficiency score of Russia? The main drawback of this study is treating the NISs as one decision unit omitting the fact that the national innovation performance cannot be analysed as one simple process with inputs and outputs. (Brando Santana et al. 2015) supposed that technological innovation should positively contribute to achieving sustainable development. The results of this study showed that Brazil, South Africa, and India have the highest efficiency scores among BRICS economies, whereas Russia and China have the worst innovation performance. Interestingly, the results of Brando et al study are exactly the opposite of the Cai and Hanley study. We suggest that the reasons behind that are as follows: (1) choosing different variables to represent the inputs and outputs of NISs, for example the inputs in the Cai and Hanley study are outputs in the Brando et al study, (2) using different scales and returns orientations, and (3) using different bias test analysis.

Summing up, there were numerous studies that used the DEA methods to measure the efficiency of NISs. However, very limited studies conducted this analysis on BRICS's NISs, and those who used it got different and conflicting results because of various reasons as mentioned earlier. Therefore, this study endeavours to fill this research gap by (1) conducting bias-corrected DEA network analysis on the BRICS's NISs, and (2) considering 
the complexity of the national innovation activities by splitting the national innovation processes into two subprocesses.

\section{Methodology and Data}

Drawing on the seminal work of (Charnes et al. 1978) who proposed a nonparametric programming model (CCR) to measure the efficiency of different decision making units (DMU), and the dual convex model (BCC) introduced by (Banker et al. 1984) to measure the technical and scale efficiency with reference to the efficient frontier, we use DEA method in this study to measure the relative efficiency scores of BRICS's NISs. However, these original DEA works were developed to measure the efficiency of DMU as a whole unit (Kao 2014), without considering the performance of other sub-processes within this unit. Therefore, in this study, we use the advanced model of the DEA method, that is network DEA, which was introduced by (Färe and Grosskopf 2000; C. H. Wang et al. 1997).

The reason behind using such a method is that DEA does not assume any relative importance, weights or even mathematical hypotheses of inputs and outputs, besides, it is a nonparametric method that is less restrictive than parametric models. Moreover, the DEA is essentially based on the Pareto Optimality principle (Charnes et al. 1985), where any decision-making unit is considered inefficient if any other decision-making unit or a combination of units were able to produce the same outputs by using fewer inputs than this unit used.

Mathematically speaking, there are two main models of the DEA method based on the type of returns to scale: (1) Constant Return to Scale (CRS), where outputs increase constantly with each increase in inputs. This model is used when all the decision-making units (DMUs) work at an optimal scale. (2) Variable Return to Scale (VRS). In this model, the returns take three directions: (A) increased, (B) decreased, and (C) Constant. According to this model, changes in the returns are not proportional to changes in inputs. This model is appropriate when all the DMUs do not work at the optimal scale or work at different scales. Both models are represented in figure 1. 


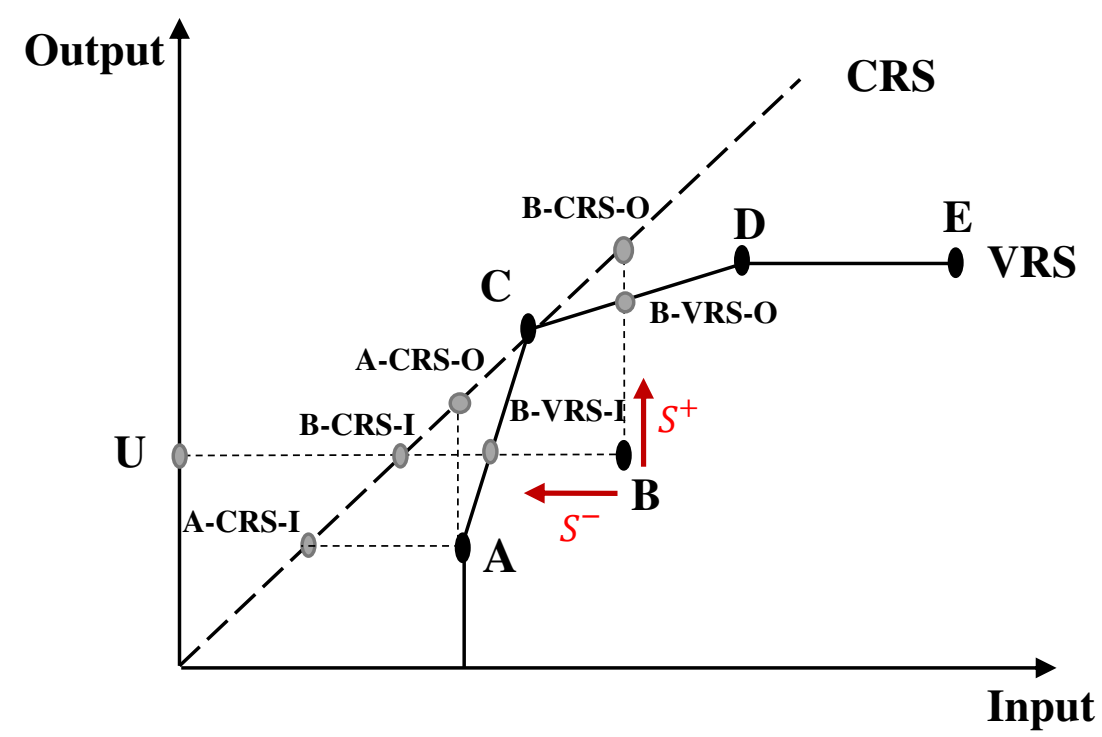

Fig. 1 CRS and VRS DEA Models

As shown in figure $1, \mathrm{DMU}_{\mathrm{B}}$, for example, is not efficient. In order to be efficient, it has to move towards one of the frontiers (DMUs). This movement takes two ways: either to the point B-VRS-I, if the DMU $U_{\mathrm{B}}$ is oriented toward inputs minimization and works at variable returns to scale (VRS), or to the point B-VRS-O, if the DMU $\mathrm{B}_{\mathrm{B}}$ activities were oriented toward outputs maximization. Moreover, there are other two possible movements if the $\mathrm{DMU}_{\mathrm{B}}$ works at constant returns to scale (CRS): (1) toward the point B-CRS-I, if the DMU $\mathrm{B}$ is oriented toward inputs minimization, (2) toward the point B-CRS-O, if the $\mathrm{DMU}_{\mathrm{B}}$ is oriented toward outputs maximization. All previous combinations are possible solutions for the $\mathrm{DMU}_{\mathrm{B}}$ to be an efficient DMU. The methodology of this study is derived from this core idea about the DEA.

In this study, as mentioned earlier, the NIS was divided into two sub-processes:

- Knowledge Production Process (KPP): at this stage, the efficiency of the technical and scientific knowledge production process is measured. The main actors in this process are the universities and R\&D organizations.

- Knowledge Commercialization Process (KCP): at this stage, the efficiency of the knowledge monetization process is measured. In other words, the efficiency of transforming technical and scientific knowledge into innovation products and new technologies. The inputs of this process are at the same time the outputs of the previous process (KPP), in addition to the other inputs that are not outputs of the KPP and related to the national innovation process. 
The inputs and outputs of these two processes were taken at different time intervals with a time lag of two years between the inputs of the KPP and the outputs of the KCP. As shown in figure 2, each process includes three inputs and two outputs variables (see the descriptive statistics of all included variables in Appendix A, table 1).

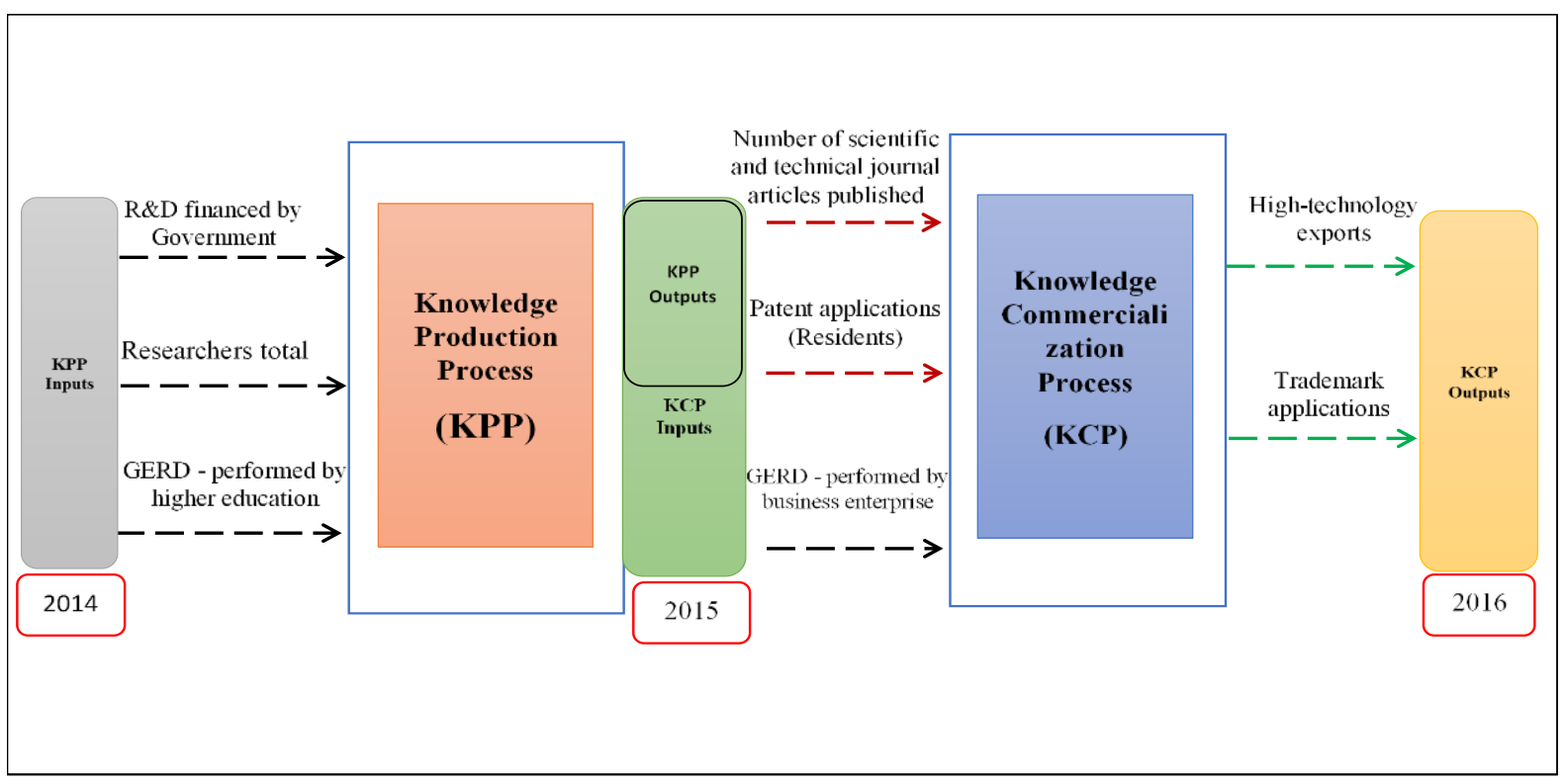

Fig 2. NIS's sub-processes

Selecting the sample of countries was based on two criteria. First, according to (Cooper et al. 2006), the number of studied countries should be greater than the combined number of inputs and outputs. Otherwise, a large portion of studied countries will be identified as efficient due to an inadequate number of degrees of freedom. Accordingly, the number of studied countries should exceed the combined number of inputs and outputs by several times. Second, we chose counties from the OECD group, where this group of countries is considered, to some extent, similar to the BRICS countries in terms of economic performance. We argue, that comparing BRICS economies with other least developed economies will not help in showing the real innovation performance of this group of countries.

The methodology consists of three stages:

A. Inputs and outputs selection: this selection was based on an extended review of previous empirical studies that used different DEA methods to measure the efficiency of NIS-related processes as shown in appendix A, table 2 .

After that, a correlation matrix analysis was done to ensure that inputs and outputs have a significant correlation. The correlation matrixes of three NIS's processes are represented in Appendix A, tables 3, 4, and 5. The reason 
behind conducting the correlation matrixes analysis is to test the construct validity of our model (Golany and Roll 1989; Lu et al. 2014). The results of the correlation matrixes analysis show that all inputs and outputs of all processes are significantly correlated. This means that the DEA model of NIS's sub-processes has high construct validity.

B. Returns selection: in order to select what kind of returns to scale we will use in our model, we draw on the work of (Kneip et al. 2011) in identifying the return to scale (RTS) by conducting a RTS-test for all three processes: KPP, KCP and Total. The Null hypothesis of this test is that the appropriate returns to scale are the constant returns to scale. The results of this test are represented in Appendix A, table 6.

Results in table 6 show that variable returns to scale (VRS) is the appropriate method to use for all processes, where the p-value of all processes leads to rejecting the null hypothesis at $\alpha=10 \%$. This means that the variable returns to scale will be used in this study. In this context, it worth mentioning that the RTS-test results are consistent with the structure of the studied NISs (DMUs) in this study, where all of them work at different scales. Moreover, the constant returns to scale method essentially measures scale efficiency without providing any information about the stage or the returns direction of the innovation activities. On the other hand, the variable returns to scale method measures the management efficiency of the innovation process regardless of the size of DMU. It is also better in identifying the future directions of the national innovation policies, both at the level of knowledge production and the commercialization of this knowledge. It also should be noted, that all studied NISs in this study operate under incomplete competition with different institutional structures. Therefore, the variable returns to scale will be adopted in this study.

C. Orientation selection: Input-oriented model with variable returns to scale was selected in the knowledge production process (KPP), where actors in general, and the government in particular, are able to control inputs more than outputs at this stage. In addition, this stage is the first stage in the innovation process, thus focusing on the input side to build the national innovation and technological capabilities and capacities needed to produce scientific and technical knowledge is the core objective at this stage. Regarding the knowledge commercialization process $(\mathrm{KCP})$, Output-oriented model with variable returns to scale was selected, since the main objective of the companies and the system is to maximize the outputs of the innovation process as much as possible.

\subsection{Efficiency measurement model}


We have two processes, where each DMU, NIS in this study, has $m^{1}$ inputs $X_{i^{1} j}\left(i^{1}=1, \ldots . m^{1}\right)$ and $s^{1}$ outputs $Y_{r^{1} j}\left(r^{1}=1, \ldots, s^{1}\right)$ for the KPP, and has $m^{2}$ inputs $X_{i^{2} j}\left(i^{2}=1, \ldots, m^{2}\right)$ and $s^{2}$ outputs $Y_{r^{2} j}\left(r^{2}=1, \ldots, s^{2}\right)$ for the KCP. Moreover, there are $\mathrm{P}$ intermediate $Z_{p j}(p=1, \ldots, q)$. These intermediates are the link between the KPP and KCP. Let $u_{r^{1}}, u_{r^{2}}, v_{i^{1}}, v_{i^{2}}$ and $w_{p}$ denote unknown positive values above $\varepsilon$ (non-Archimedean number).

The overall efficiency of NIS can be defined as follows:

$$
E_{j}=\frac{\sum_{r^{1}=1}^{s^{1}} u_{r_{1}} Y_{r_{j}}+\sum_{r^{2}=1}^{s^{2}} u_{r_{2}} Y_{r_{j}}+\sum_{p=1}^{q} w_{p} z_{p j}}{\sum_{i^{1}=1}^{m_{1}^{1}} v_{i_{1}} x_{i^{1} j}+\sum_{i^{2}=1}^{m^{2}} v_{i_{2}} x_{i^{2} j}+\sum_{p=1}^{q} w_{p} z_{p j}}
$$

$\boldsymbol{E}_{\boldsymbol{j}}$ is the ratio of the aggregated weighted outputs to the aggregated weighted inputs of the two processes. The overall efficiency $\boldsymbol{E}_{\boldsymbol{j}}$ is a combination of two efficiencies $E_{j}^{1}$ for the KPP efficiency score and $E_{j}^{2}$ for the KCP efficiency score. So, the overall convex efficiency can be defined as follows:

$$
E_{j}=()_{j} E_{j}^{1}+\left(1-()_{j}\right) E_{j}^{2} \quad(\text { Eq. } 2)
$$

where

$$
E_{j}^{1}=\frac{\sum_{r^{1}=1}^{s^{1}} u_{r_{1} Y} r^{1}{ }^{1}+\sum_{p=1}^{q} w_{p} z_{p j}}{\sum_{i^{1}=1}^{m^{1}} v_{i_{1}} x_{i^{1}}} \epsilon(0,1]
$$

and

$$
E_{j}^{2}=\frac{\sum_{r^{2}=1}^{s^{2}} u_{r_{2}} Y_{r^{2} j}}{\sum_{i^{2}=1}^{m^{2}} v_{i_{2}} x_{i^{2}}+\sum_{p=1}^{q} w_{p} z_{p j}} \epsilon(0,1] \text { (Eq. 2.2) }
$$

and

$$
\bigcup_{j}=\frac{\sum_{i^{1}=1}^{m^{1}} v_{i_{1}} x_{i^{1}}}{\sum_{i^{1}=1}^{m^{1}} v_{i_{1}} x_{i^{1} j}+\sum_{i^{2}=1}^{m^{2}} v_{i_{2}} x_{i^{2} j}+\sum_{p=1}^{q} w_{p} z_{p j}} \epsilon[0,1] \text { (Eq. 2.3) }
$$

()$_{j}$ denote the utilized portion of system aggregate inputs in the KPP, while $1-()_{j}$ is the utilized portion of the system aggregate inputs in the KCP.

Based on (Kao and Hwang 2008), the outputs of the first process (KPP) should be the inputs of the second process (KCP). So, the CRS model (Charnes et al. 1978) of the overall efficiency of a $D M U_{j_{0}}$ can be calculated as follows: 


$$
\begin{aligned}
& E_{j_{0}}=\max \frac{\sum_{r 1=1}^{s^{1}} u_{r_{1}} Y_{r^{1} j_{0}}+\sum_{r^{2}=1}^{s^{2}} u_{r_{2}} Y_{r^{2} j_{0}}+\sum_{p=1}^{q} w_{p} z_{p j_{0}}}{\sum_{i^{1}=1}^{m^{1}} v_{i_{1}} x_{i^{1} j_{0}}+\sum_{i^{2}=1}^{m^{2}} v_{i_{2}} x_{i^{2} j_{0}}+\sum_{p=1}^{q} w_{p} z_{p j_{0}}} \text { (Eq. 3) } \\
& \text { s.t. } \quad \frac{\sum_{r^{1}=1}^{s^{1}} u_{r_{1}} Y_{r^{1} j}+\sum_{r^{2}=1}^{s^{2}} u_{r_{2}} Y_{r^{2} j}+\sum_{p=1}^{q} w_{p} z_{p j}}{\sum_{i^{1}=1}^{m^{1}} v_{i_{1}} x_{i^{1} j}+\sum_{i^{2}=1}^{m^{2}} v_{i_{2}} x_{i^{2} j}+\sum_{p=1}^{q} w_{p} z_{p j}} \leq 1 \\
& \frac{\sum_{r^{1}=1}^{s^{1}} u_{r_{1}} Y_{r^{1} j}+\sum_{p=1}^{q} w_{p^{z}} z_{j j}}{\sum_{i^{1}=1}^{m^{1}} v_{i_{1}} x_{i^{1} j}} \leq 1 \\
& \frac{\sum_{r^{2}=1}^{s^{2}} u_{r_{2} Y_{r^{2} j}}}{\sum_{i^{2}=1}^{m^{2}} v_{i_{2}} x_{i^{2} j}+\sum_{p=1}^{q} w_{p} z_{p j}} \leq 1
\end{aligned}
$$

where $u_{r^{1}}, u_{r^{2}}, v_{i^{1}}, v_{i^{2}}$ and $w_{p} \geq \varepsilon ; j=1,2, \ldots, n$

Transformation the previous model into a linear program model can be solved as follows:

$$
\begin{gathered}
E_{j_{0}}=\max \sum_{r^{1}=1}^{s^{1}} u_{r_{1}} Y_{r^{1} j_{0}}+\sum_{r^{2}=1}^{s^{2}} u_{r_{2}} Y_{r^{2} j_{0}}+\sum_{p=1}^{q} w_{p} z_{p j_{0}} \\
\text { s.t. } \quad \sum_{i^{1}=1}^{m^{1}} v_{i_{1}} x_{i^{1} j_{0}}+\sum_{i^{2}=1}^{m^{2}} v_{i_{2}} x_{i^{2} j_{0}}+\sum_{p=1}^{q} w_{p} z_{p j_{0}}=1 \\
\left(\sum_{r^{1}=1}^{s^{1}} u_{r_{1}} Y_{r^{1} j}+\sum_{p=1}^{q} w_{p} z_{p j}\right)-\sum_{i^{1}=1}^{m^{1}} v_{i_{1}} x_{i^{1} j} \leq 0 \\
\sum_{r^{2}=1}^{s^{2}} u_{r_{2}} Y_{r^{2} j}-\left(\sum_{i^{2}=1}^{m^{2}} v_{i_{2}} x_{i^{2} j}+\sum_{p=1}^{q} w_{p} z_{p j}\right) \leq 0
\end{gathered}
$$

where $u_{r^{1}}, u_{r^{2}}, v_{i^{1}}, v_{i^{2}}$ and $w_{p} \geq \varepsilon ; j=1,2, \ldots, n$

In the same way, we calculate the efficiency of two sup-processes (KPP and KCP).

$$
\begin{gathered}
E_{j_{0}}^{1}=\max \sum_{r^{1}=1}^{s^{1}} u_{r_{1}} Y_{r^{1} j_{0}}+\sum_{p=1}^{q} w_{p} z_{p j_{0}} \\
\text { s.t. } \quad \sum_{i^{1}=1}^{m^{1}} v_{i_{1}} x_{i^{1} j_{0}}=1 \\
\left(\sum_{r^{1}=1}^{s^{1}} u_{r_{1}} Y_{r^{1} j_{0}}+\sum_{p=1}^{q} w_{p} z_{p j_{0}}+\sum_{r^{2}=1}^{s^{2}} u_{r_{2}} Y_{r^{2} j_{0}}\right)-E_{j_{0}}\left(\sum_{i^{1}=1}^{m^{1}} v_{i_{1}} x_{i^{1} j_{0}}+\sum_{i^{2}=1}^{m^{2}} v_{i_{2}} x_{i^{2} j_{0}}+\sum_{p=1}^{q} w_{p} z_{p j_{0}}\right)= \\
0 \\
\left(\sum_{r^{1}=1}^{s^{1}} u_{r_{1}} Y_{r^{1} j}+\sum_{p=1}^{q} w_{p} z_{p j}\right)-\sum_{i^{1}=1}^{m^{1}} v_{i_{1}} x_{i^{1} j} \leq 0 \\
\sum_{r^{2}=1}^{s^{2}} u_{r_{2}} Y_{r^{2} j}-\left(\sum_{p=1}^{q} w_{p} z_{p j}+\sum_{i^{1}=1}^{m^{1}} v_{i_{1}} x_{i^{1} j}\right) \leq 0
\end{gathered}
$$


where $u_{r^{1}}, u_{r^{2}}, v_{i^{1}}, v_{i^{2}}$ and $w_{p} \geq \varepsilon ; j=1,2, \ldots, n$

$$
\begin{aligned}
& \text { and } \\
& E_{j_{0}}^{2}=\max \sum_{r^{2}=1}^{s^{2}} u_{r_{2}} Y_{r^{2} j_{0}}+\sum_{p=1}^{q} w_{p} z_{p j_{0}} \quad \text { (Eq. 6) } \\
& \text { s.t. } \quad \sum_{i^{2}=1}^{m^{2}} v_{i_{2}} x_{i^{2} j_{0}}+\sum_{p=1}^{q} w_{p} z_{p j_{0}}=1 \\
& \left(\sum_{r^{1}=1}^{s^{1}} u_{r_{1}} Y_{r^{1} j_{0}}+\sum_{p=1}^{q} w_{p} z_{p j_{0}}+\sum_{r^{2}=1}^{s^{2}} u_{r_{2}} Y_{r^{2} j_{0}}\right)-E_{j_{0}}\left(\sum_{i^{1}=1}^{m^{1}} v_{i_{1}} x_{i^{1} j_{0}}+\sum_{i^{2}=1}^{m^{2}} v_{i_{2}} x_{i^{2} j_{0}}+\sum_{p=1}^{q} w_{p} z_{p j_{0}}\right)= \\
& 0 \\
& \left(\sum_{r^{1}=1}^{s^{1}} u_{r_{1}} Y_{r^{1} j}+\sum_{p=1}^{q} w_{p^{2}} z_{p j}\right)-\sum_{i^{1}=1}^{m^{1}} v_{i_{1}} x_{i^{1} j} \leq 0 \\
& \sum_{r^{2}=1}^{s^{2}} u_{r_{2}} Y_{r^{2} j}-\left(\sum_{p=1}^{q} w_{p} z_{p j}+\sum_{i^{1}=1}^{m^{1}} v_{i_{1}} x_{i^{1} j}\right) \leq 0
\end{aligned}
$$

where $u_{r^{1}}, u_{r^{2}}, v_{i^{1}}, v_{i^{2}}$ and $w_{p} \geq \varepsilon ; j=1,2, \ldots, n$

All previous models (eq. 1 to eq. 6) work under the assumption of constant returns to scale (CRS) and outputs oriented, but the RTS-test showed that the appropriate model is the variable returns to scale (VRS) with an inputsoriented model for the KPP and outputs-oriented for the KCP and the overall innovation process. Therefore, deriving from(Banker et al. 1984; Y. Chen et al. 2009; Didenko et al. 2017; Guan and Chen 2012; Y.-M. Wang and Chin 2010), the previous models are transformed as follows:

\subsubsection{VRS-output-oriented model of the overall innovation process (NIS)}

The primal equation of VRS-output-oriented model is as follows:

$$
\begin{gathered}
\theta_{j_{0}}=\min \sum_{i^{1}=1}^{m^{1}} v_{i_{1}} x_{i^{1} j_{0}}+\sum_{i^{2}=1}^{m^{2}} v_{i_{2}} x_{i^{2} j_{0}}+\sum_{p=1}^{q} w_{p} z_{p j_{0}}-\mu_{j_{0}}^{1}-\mu_{j_{0}}^{2} \text { (Eq. 7) } \\
\text { s.t. } \sum_{i^{1}=1}^{m^{1}} v_{i_{1}} x_{i^{1} j}+\sum_{i^{2}=1}^{m^{2}} v_{i_{2}} x_{i^{2} j}+\sum_{p=1}^{q} w_{p} z_{p j}-\left(\sum_{r^{1}=1}^{s^{1}} u_{r_{1}} Y_{r^{1} j}+\sum_{p=1}^{q} w_{p} z_{p j}+\sum_{r^{2}=1}^{s^{2}} u_{r_{2}} Y_{r^{2} j}\right)-\mu_{j_{0}}^{1}- \\
\mu_{j_{0}}^{2} \geq 0 \\
\sum_{r^{1}=1}^{s^{1}} u_{r_{1}} Y_{r^{1} j_{0}}+\sum_{r^{2}=1}^{s^{2}} u_{r_{2}} Y_{r^{2} j_{0}}+\sum_{p=1}^{q} w_{p} z_{p j_{0}}=1
\end{gathered}
$$

where $u_{r^{1}}, u_{r^{2}}, v_{i^{1}}, v_{i^{2}}$ and $w_{p} \geq \varepsilon ; j=1,2, \ldots, n$ 
$\mu_{j_{0}}^{1}$ and $\mu_{j_{0}}^{2}$ represent the direction of returns and they are free of sign scalers that used in the VRS model. So, if $\mu_{j_{0}}>0$, this means we have decreased returns, if $\mu_{j_{0}}<0$, this means we have increased returns, and if $\mu_{j_{0}}=0$, then the returns are constant.

The dual linear programming model is as follows:

$$
\begin{gathered}
\max _{0} \quad \text { (Eq. 8) } \\
\text { s.t. } \theta_{0}\left(\sum_{r^{1}=1}^{s^{1}} u_{r_{1}} Y_{r^{1} j_{0}}+\sum_{r^{2}=1}^{s^{2}} u_{r_{2}} Y_{r^{2} j_{0}}+\sum_{p=1}^{q} w_{p} z_{p j_{0}}\right)-\left(\sum_{r^{1}=1}^{s^{1}} \lambda_{r_{1}} Y_{r^{1} j}+\sum_{p=1}^{q} \lambda_{p} z_{p j}+\right. \\
\left.\sum_{r^{2}=1}^{s^{2}} \lambda_{r_{2}} Y_{r^{2} j}\right) \leq 0 \\
\left(\sum_{i^{1}=1}^{m^{1}} v_{i_{1}} x_{i^{1} j_{0}}+\sum_{i^{2}=1}^{m^{2}} v_{i_{2}} x_{i^{2} j_{0}}+\sum_{p=1}^{q} w_{p} z_{p j_{0}}\right)-\left(\sum_{i^{1}=1}^{m^{1}} \lambda_{i_{1}} x_{i^{1} j}+\sum_{i^{2}=1}^{m^{2}} \lambda_{i_{2}} x_{i^{2} j}+\sum_{p=1}^{q} \lambda_{p} z_{p j}\right) \geq 0 \\
\sum_{j=1}^{n} \lambda_{j}=1
\end{gathered}
$$

Where $\lambda_{j} \geq 0$ and represents the associated weighting of outputs and inputs of $\mathrm{DMU}_{\mathrm{j}}$.

\subsubsection{VRS-input-oriented model of KPP}

The primal equation of VRS-input-oriented model is as follows:

$$
\theta_{j_{0}}^{1}=\max \sum_{r^{1}=1}^{s^{1}} u_{r_{1}} Y_{r^{1} j_{0}}+\sum_{p=1}^{q} w_{p} z_{p j_{0}}+\mu_{j_{0}}^{1} \text { (Eq. 9) }
$$

s.t. $\quad \sum_{i^{1}=1}^{m^{1}} v_{i_{1}} x_{i^{1} j}-\left(\sum_{r^{1}=1}^{s^{1}} u_{r_{1}} Y_{r^{1} j}+\sum_{p=1}^{q} w_{p} z_{p j}\right) \geq 0$

$$
\sum_{i^{1}=1}^{m^{1}} v_{i_{1}} x_{i^{1} j_{0}}=1
$$

where $u_{r^{1}}, u_{r^{2}}, v_{i^{1}}, v_{i^{2}}$ and $w_{p} \geq \varepsilon ; j=1,2, \ldots, n$

The dual linear programming model is as follows:

$$
\begin{gathered}
\min \theta_{j_{0}}^{1} \text { (Eq. 10) } \\
\text { s.t. }\left(\sum_{r^{1}=1}^{s^{1}} u_{r_{1}} Y_{r^{1} j_{0}}+\sum_{p=1}^{q} w_{p} z_{p j_{0}}\right)-\left(\sum_{r^{1}=1}^{s^{1}} \lambda_{r_{1}} Y_{r^{1} j}+\sum_{p=1}^{q} \lambda_{p} z_{p j}\right) \leq 0 \\
\theta_{j_{0}}^{1} \sum_{i^{1}=1}^{m^{1}} v_{i_{1}} x_{i^{1} j_{0}}-\sum_{i^{1}=1}^{m^{1}} \lambda_{i_{1}} x_{i^{1} j} \geq 0 \\
\sum_{j=1}^{n} \lambda_{j}=1
\end{gathered}
$$




$$
\lambda_{j} \geq 0
$$

\subsubsection{VRS-output-oriented model of KCP}

The primal equation of VRS-output-oriented model is as follows:

$$
\begin{gathered}
\theta_{j_{0}}^{2}=\min \sum_{i^{2}=1}^{m^{2}} v_{i_{2}} x_{i^{2} j_{0}}+\sum_{p=1}^{q} w_{p} z_{p j_{0}}-\mu_{j_{0}}^{2} \text { (Eq. 11) } \\
\text { s.t. }\left(\sum_{i^{2}=1}^{m^{2}} v_{i_{2}} x_{i^{2} j}+\sum_{p=1}^{q} w_{p} z_{p j}\right)-\sum_{r^{2}=1}^{s^{2}} u_{r_{2}} Y_{r^{2} j}-\mu_{j_{0}}^{2} \geq 0 \\
\sum_{r^{2}=1}^{s^{2}} u_{r_{2}} Y_{r^{2} j_{0}}=1
\end{gathered}
$$

where $u_{r^{1}}, u_{r^{2}}, v_{i^{1}}, v_{i^{2}}$ and $w_{p} \geq \varepsilon ; j=1,2, \ldots, n$

The dual linear programming model is as follows:

$$
\begin{gathered}
\max \theta_{j_{0}}^{2} \\
\text { s.t. } \theta_{j_{0}}^{2} \sum_{r^{1}=1}^{s^{1}} u_{r_{1}} Y_{r^{1} j_{0}}-\sum_{r^{1}=1}^{s^{1}} \lambda_{r_{1}} Y_{r^{1} j} \leq 0 \\
\left(\sum_{i^{2}=1}^{m^{2}} v_{i_{2}} x_{i^{2} j_{0}}+\sum_{p=1}^{q} w_{p} z_{p j_{0}}\right)-\left(\sum_{i^{2}=1}^{m^{2}} \lambda_{i_{2}} x_{i^{2} j}+\sum_{p=1}^{q} \lambda_{p} z_{p j}\right) \geq 0 \\
\sum_{j=1}^{n} \lambda_{j}=1 \\
\lambda_{j} \geq 0
\end{gathered}
$$

\section{Results and discussion}

As shown in table 7, the results of VRS-input-oriented model show that only 10 of 24 countries are efficient in producing scientific and technical knowledge (KPP), whereas the results of VRS-output-oriented model show that only 12 of 24 countries are efficient in terms of commercializing this knowledge (KCP). On the other hand, the results of DEA for the total innovation process show that only 13 of 24 countries are efficient. It should be mentioned here that the VRS model measures the efficiency of resources management, not the scale efficiency because all studied NISs work under different scales. 
Table 7. DEA Network Results

\begin{tabular}{|c|c|c|c|c|c|c|c|c|c|c|c|}
\hline DMU & $\begin{array}{c}\text { KPP } \\
\text { efficiency } \\
\text { score }\end{array}$ & $\begin{array}{c}\text { Bias- } \\
\text { corr.KPP } \\
\text { efficiency } \\
\text { score }\end{array}$ & KPP.Rank & $\begin{array}{c}\text { KCP } \\
\text { efficiency } \\
\text { score }\end{array}$ & $\begin{array}{c}\text { Bias- } \\
\text { corr.KCP } \\
\text { efficiency } \\
\text { score }\end{array}$ & KCP.Rank & $\begin{array}{c}\text { Total } \\
\text { efficiency } \\
\text { score }\end{array}$ & $\begin{array}{c}\text { Bias- } \\
\text { corr.Total } \\
\text { efficiency } \\
\text { score }\end{array}$ & Total.Rank & $\begin{array}{c}\text { Average } \\
\text { Efficiency } \\
\text { Score }\end{array}$ & $\begin{array}{c}\text { Final } \\
\text { Efficiency } \\
\text { Rank }\end{array}$ \\
\hline $\mathbf{R U}$ & 0.601 & 0.509 & 23 & 0.517 & 0.323 & 15 & 0.602 & 0.458 & 19 & 0.430 & 23 \\
\hline $\mathbf{C N}$ & 1 & 0.768 & 10 & 1 & 0.238 & 19 & 1 & 0.520 & 15 & 0.508 & 17 \\
\hline IND & 1 & 0.813 & 4 & 1 & 0.388 & 10 & 1 & 0.437 & 20 & 0.546 & 14 \\
\hline BRA & 1 & 0.763 & 11 & 1 & 0.291 & 17 & 1 & 0.366 & 22 & 0.473 & 21 \\
\hline $\mathbf{Z A F}$ & 1 & 0.714 & 16 & 1 & 0.144 & 23 & 1 & 0.552 & 13 & 0.470 & 22 \\
\hline AUT & 0.645 & 0.526 & 22 & 0.356 & 0.201 & 21 & 0.351 & 0.246 & 24 & 0.324 & 24 \\
\hline BEL & 0.806 & 0.665 & 20 & 1 & 0.449 & 5 & 0.888 & 0.650 & 5 & 0.588 & 4 \\
\hline CAN & 0.932 & 0.793 & 7 & 0.701 & 0.406 & 9 & 0.741 & 0.546 & 14 & 0.582 & 6 \\
\hline DNK & 1 & 0.755 & 14 & 0.400 & 0.258 & 18 & 1 & 0.476 & 17 & 0.496 & 19 \\
\hline FIN & 0.995 & 0.850 & 2 & 0.301 & 0.171 & 22 & 0.951 & 0.688 & 2 & 0.569 & 10 \\
\hline FRA & 0.571 & 0.497 & 24 & 0.946 & 0.616 & 2 & 0.775 & 0.608 & 10 & 0.574 & 8 \\
\hline $\mathrm{DEU}$ & 0.689 & 0.585 & 21 & 1 & 0.360 & 11 & 1 & 0.636 & 6 & 0.527 & 15 \\
\hline ITA & 1 & 0.790 & 9 & 0.661 & 0.441 & 6 & 0.621 & 0.467 & 18 & 0.566 & 11 \\
\hline
\end{tabular}




\begin{tabular}{|c|c|c|c|c|c|c|c|c|c|c|c|}
\hline KOR & 1 & 0.790 & 8 & 0.704 & 0.426 & 7 & 0.685 & 0.493 & 16 & 0.570 & 9 \\
\hline NLD & 0.786 & 0.671 & 19 & 1 & 0.418 & 8 & 1 & 0.633 & 7 & 0.574 & 7 \\
\hline NOR & 0.988 & 0.853 & 1 & 1 & 0.320 & 16 & 1 & 0.598 & 11 & 0.590 & 3 \\
\hline POL & 0.951 & 0.813 & 5 & 0.544 & 0.352 & 12 & 0.441 & 0.332 & 23 & 0.499 & 18 \\
\hline PRT & 1 & 0.756 & 13 & 1 & 0.113 & 24 & 1 & 0.608 & 9 & 0.493 & 20 \\
\hline SGP & 0.788 & 0.688 & 18 & 1 & 0.342 & 13 & 1 & 0.650 & 4 & 0.560 & 12 \\
\hline ESP & 0.913 & 0.807 & 6 & 0.770 & 0.468 & 4 & 0.537 & 0.371 & 21 & 0.549 & 13 \\
\hline SWE & 0.836 & 0.704 & 17 & 0.384 & 0.233 & 20 & 0.828 & 0.627 & 8 & 0.521 & 16 \\
\hline TUR & 0.859 & 0.759 & 12 & 1 & 0.593 & 3 & 1 & 0.651 & 3 & 0.668 & 2 \\
\hline UK & 1 & 0.729 & 15 & 0.947 & 0.666 & 1 & 1 & 0.742 & 1 & 0.712 & 1 \\
\hline USA & 1 & 0.820 & 3 & 1 & 0.335 & 14 & 1 & 0.594 & 12 & 0.583 & 5 \\
\hline
\end{tabular}

Final efficiency rank is the average ranking value of three processes: KPP, KCP and Total innovation process. 
Regarding the efficiency scores of the BRICS NISs, all of them were ranked at the bottom of the studied countries list. Moreover, BRICS economies suffer from low performance in terms of knowledge commercialization, where all of them have a very low-efficiency score in comparison to other studied countries. On the other hand, the performance of BRICS economies in terms of knowledge production is better than their performance in commercializing this knowledge, where India and China perform well in comparison to other BRICS countries.

To identify what measures need to be taken to make the knowledge production and knowledge commercialization processes work efficiently, a projection analysis was done. The values of projection analysis, as shown in Appendix A, table 8, were calculated through the equations 8,10 , and 12 . The results in table 8 show how much countries should decrease their innovation inputs, in inputs-oriented model, or increase innovation outputs, in outputs-oriented model, to work at optimal scale with the best possible efficient performance.

A country like Russia, for example, suffers from a low performance at both innovation-related processes: KPP and KCP. The projections analysis in Appendix A, table 8 of KPP efficiency score in Russia shows that if Russia wants to achieve the KPP efficiency score of $100 \%$ (1.00) with the current level of output variables, Russia should decrease expenditure on R\&D by government and education sector (X1 and X3) by $60.1 \%$ and the number of researchers (X2) by 33.5\%. These figures indicate incompetence in managing the inputs of KPP. In other words, this low performance at both innovation-related processes represents the waste of resources that can be reallocated in other areas such as creating business incubators, innovation parks, and technological clusters. 
Table 8. DEA's Projection Results

\begin{tabular}{|c|c|c|c|c|c|c|c|}
\hline \multirow[b]{2}{*}{ DMU } & \multicolumn{3}{|c|}{ KPP Projections } & \multicolumn{2}{|c|}{ KCP Projections } & \multicolumn{2}{|c|}{ Total Projections } \\
\hline & $\begin{array}{c}\text { R\&D financed by } \\
\text { Government }\end{array}$ & Researchers total & $\begin{array}{c}\text { GERD - } \\
\text { performed by } \\
\text { higher education }\end{array}$ & $\begin{array}{c}\text { High- } \\
\text { technology } \\
\text { exports }\end{array}$ & Trademark applications & $\begin{array}{c}\text { High-technology } \\
\text { exports }\end{array}$ & $\begin{array}{l}\text { Trademark } \\
\text { applications }\end{array}$ \\
\hline RU & -60.1 & -60.1 & -33.5 & 193.3 & 193.3 & 166.2 & 166.2 \\
\hline $\mathbf{C N}$ & 100 & 100 & 100 & 100 & 100 & 100 & 100 \\
\hline IND & 100 & 100 & 100 & 100 & 100 & 100 & 100 \\
\hline BRA & 100 & 100 & 100 & 100 & 100 & 100 & 100 \\
\hline ZAF & 100 & 100 & 100 & 100 & 100 & 100 & 100 \\
\hline AUT & -56 & -50.6 & -64.5 & 280.7 & 280.7 & 285 & 285.0 \\
\hline BEL & -80.6 & -80.6 & -80.6 & 100 & 100 & 112.6 & 112.6 \\
\hline CAN & -93.2 & -67.2 & -93.2 & 142.6 & 142.6 & 134.9 & 134.9 \\
\hline DNK & 100 & 100 & 100 & 250.1 & 601.7 & 100 & 100 \\
\hline FIN & -99.5 & -99.5 & -86.4 & 332.7 & 385.7 & 105.1 & 547 \\
\hline FRA & -57.1 & -57.1 & -57.1 & 105.7 & 105.7 & 129.0 & 129 \\
\hline DEU & -55.8 & -68.9 & -68.9 & 100 & 100 & 100 & 100 \\
\hline ITA & 100 & 100 & 100 & 151.3 & 151.3 & 160.9 & 160.9 \\
\hline
\end{tabular}




\begin{tabular}{|c|c|c|c|c|c|c|c|}
\hline KOR & 100 & 100 & 100 & 142 & 142 & 145.9 & 145.9 \\
\hline NLD & -78.6 & -71 & -78.6 & 100 & 100 & 100 & 100 \\
\hline NOR & -98.2 & -85.4 & -98.2 & 100 & 100 & 100 & 100 \\
\hline POL & -95.1 & -95.1 & -95.1 & 183.8 & 525 & 226.9 & 226.9 \\
\hline PRT & 100 & 100 & 100 & 100 & 100 & 100 & 100 \\
\hline SGP & -78.8 & -55.6 & -78.8 & 100 & 100 & 100 & 100 \\
\hline ESP & -91.3 & -91.3 & -91.3 & 129.8 & 129.8 & 186.1 & 186.1 \\
\hline SWE & -83.6 & -63.5 & -83.6 & 260.4 & 260.4 & 120.8 & 120.8 \\
\hline TUR & -85.9 & -62.5 & -85.9 & 100 & 100 & 100 & 100 \\
\hline UK & 100 & 100 & 100 & 106.7 & 106.7 & 100 & 100 \\
\hline USA & 100 & 100 & 100 & 100 & 100 & 100 & 100 \\
\hline
\end{tabular}

The projection results are linked to the orientation models of each process, where the table includes the projection results of the inputs of the KPP since the KPP is input oriented. The results also show only the projection values of outputs variables for both KCP and total innovation process since these two processes are output oriented. 
In the same context, the projection analysis of KCP efficiency score in Russia shows that if Russia wants to achieve the KCP efficiency score of $100 \%$ (1.00), it should increase outputs of the knowledge commercialization process by $93.3 \%$. This means that the Russian innovation system has very low performance in terms of transforming the outputs of KPP into innovation products and services. This situation reveals a network system failure associated with weak linkages among universities and industry because of many institutional obstacles that generate a high-risk business environment and market uncertainty (Hekkert et al. 2007; Klein Woolthuis et al. 2005). This means that the problem in the Russian innovation system is not a problem of resources, but it is a problem of system management and institutions. This situation can be found in all other BRICS economies in different forms.

For a more in-depth analysis of the efficiency analysis results, we analyse the correlation matrix between the three models (KPP, KCP, and Total). The correlation matrix among these three processes shows the causal relationship between the overall innovation process and the sub-processes: (1) the KPP, (2) and the KCP.

According to the DEA results, NISs can be classified into four groups as shown in figure 3.

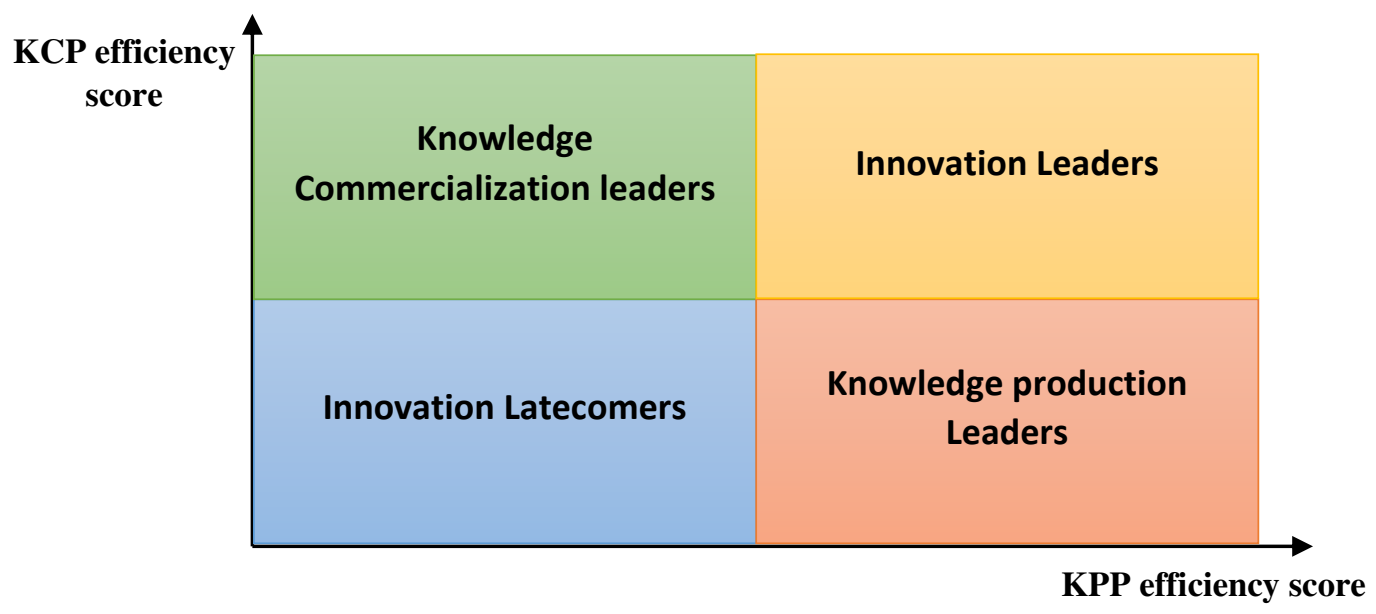

Fig 3. NISs Classification Matrix

A. Innovation latecomers: this group includes the weakest innovation systems, where both KPP and KCP do not work efficiently. As mentioned earlier, this is mainly due to poor resources management at scales that are disproportionate to the intensity and development level of innovative and technological activities. These countries need to reduce the KPP inputs and focus on reallocating their resources based on adopting new management paradigms. Without doing so, any further investments in the KCP will be futile as long as the outputs of KPP are low. 
B. Knowledge production leaders: this group includes NISs with a good education system with a good efficiency score of KPP. However, the commercialization process of the outputs of KPP does not work efficiently. Therefore, these countries should improve the synergistic relationships between main NIS's actors by building bridging organizations, enablers and a stimulating institutional environment. Moreover, promoting trade openness and protecting intellectual property rights are essential prerequisites for utilizing patents and technology transfer.

C. Knowledge commercialization leaders: this group includes NISs that have a good performance in commercializing their knowledge. However, the KPP in universities in these NISs is not up to the level of development of innovation activities in the industry. This situation leads to a weak innovation performance at the national level. This group of countries needs to reallocate R\&D resources into improving the KPP performance. In other words, enhancing mechanisms and dynamics of knowledge production in universities and research centers by supporting them through grants programs oriented towards specific national technological priorities. In addition to creating joint research programs gathering universities with business sector.

D. Innovation leaders: this group includes NISs that have a very good performance at both KPP and KCP. Countries in this group are efficient at resources management and thy work at a good scale. To maintain their leadership, these countries need to increase their innovation inputs and constantly invest in new technologies as a part of a leadership strategy. This kind of innovation behavior has a direct impact on national wealth creation.

In consistent with the previous theoretical illustration, studied NISs were classified based on the results of the DEA analysis as shown in figure 4. 


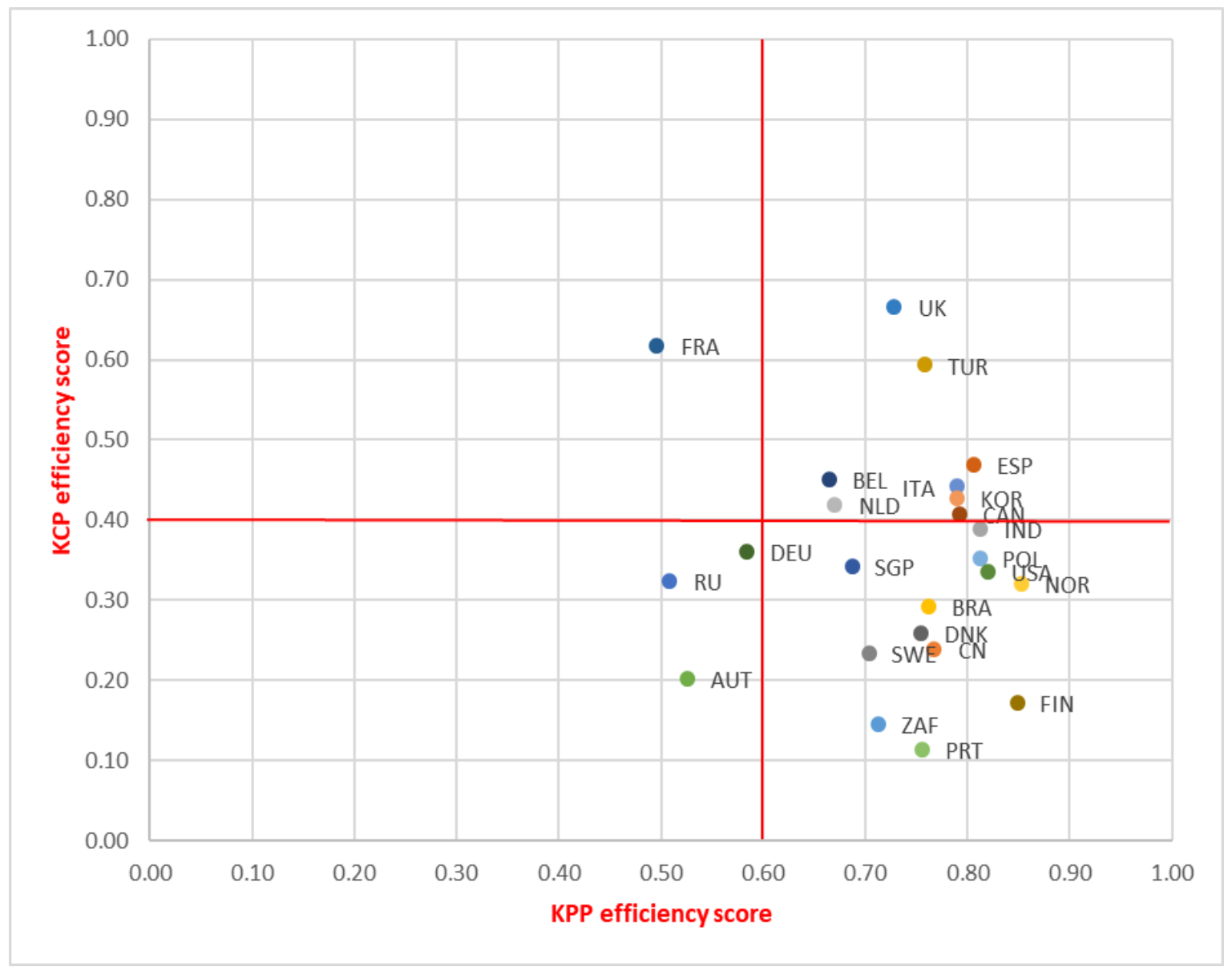

Fig 4. NISs classification based on DEA results

As shown in the previous figure, all NISs of BRICS economies, except Russia, belong to the knowledge production leaders' group. This indicates that these countries lack effective mechanisms to transform the outputs of KPP into innovation products and new technologies. The good performance of KPP in these countries is associated with low performance in commercializing the outputs of KPP. Therefore, BRICS economies need to focus their efforts on building enablers and bridging relationships between universities and industry by supporting intermediary firms and intermediary actors. These intermediary actors are considered a key element in increasing synergy among NIS's actors and facilitating the flow of knowledge, practices, and technologies among them.

Regarding the foreign investment-related policies, BRICS countries need to promote free markets and free trade and build the legal and institutional environment that stimulates the influx of foreign companies involved in innovation, not just those looking for low wage labour.

In this context, it should be mentioned that the weak link between the KPP and KCP can by caused by many other economic, political, and cultural factors. For instance, (Krasikova and Ognev 2014) showed that corruption in 
the innovation activities of universities reduces the productive interactions of them with business sector and government. In the same context, (Lobazova 2019) emphasized the role of mentality of corruption as a factor hampering innovation. On the other hand, other studies addressed the direct negative influence of political instability on the innovation system (Allard et al. 2012; Namazi and Mohammadi 2018; Pertuze Salas et al. 2019).

Regarding the political economy of the way in which the innovation system works, it can be said that the lack of institutional capacities and the weak role of the low play a decisive role in shifting the innovation strategies of the main actors in the innovation system from a partnership strategies to a lobby or corruption strategies (Fagerberg et al. 2009; Gao and Yuan 2020; Papaioannou et al. 2016). In consistence with the results of our study, we argue that most of BRICS countries suffer from the hindering effects of all previous environmental factors. These factors play an important role in shaping the political economy of innovation in this group of countries.

The aforementioned policies should coincide with a strong presence of government as a key coordinating actor in the innovation system whose main task is to stimulate entrepreneurial activities, effectively manage productive innovation relationships and create incentives for these types of activities.

The results of DEA show that some countries have a good total efficiency score, but they have low-efficiency scores in KPP or KCP. On the other hand, other countries such as BRICS countries have a low total efficiency score combined with high efficiency score of KPP and low efficiency score of KCP. Therefore, we conducted a correlation analysis between the total efficiency score and the two other sub-processes scores. Table 9 in appendix A shows that the total innovation performance of studied NISs depends more on the commercialization process of scientific and technical knowledge than on the knowledge production process. The correlation matrix also shows that there is a relationship between the total innovation performance and the KPP performance, however, this relationship is not significant enough to claim a causal relationship between these two processes.

Table 9 also shows that the relationship between KPP efficiency score and KCP efficiency score is positive but insignificant. Besides, results in Table 7 show that in most of the studied NISs the performance of KPP is better than the performance of KCP. This means that at some point, any increase in investments in KPP would cause a decrease in the KCP performance. All BRICS economies are good cases of such phenomenon. This result confirms our choice of the input-oriented model for the knowledge production process, as efficiently managing the inputs of this process would reduce the opportunity cost of investing in commercial exploitation of knowledge at the national level. 
Considering that all BRICS economies have low performance in commercializing their scientific and technical knowledge. It is important to mention that improving the commercialization of scientific and technical knowledge alone will not improve the national innovation performance of the BRICS countries, where innovation is not only technical know-how but also a socio-economic phenomenon. In this context, it is worth noting that most BRICS countries lack a national innovation paradigm. Previous studies (Miravitlles et al. 2017; Y. Wang and Li-Ying 2014) have shown that these countries tend to imitate foreign technological models rather than developing a local model based on local capabilities. In addition, most of BRICS countries suffer from the problem of translating technological developments into improvements in social and economic conditions. This makes governments lack the resources, expertise, and legitimacy to develop a national innovation industrial behaviour.

\section{Limitations}

The introduced framework analysis of DEA is a one-way path, where it does not consider the other innovation channels that contribute to the national innovation performance such as social innovation and the spillovers of other innovation agents' interactions. Moreover, we think that studying the impact of the political economy related factors such as political system, and corruption on the total performance of innovation system would provide a different research perspective in the innovation studies. So, considering these other research aspects of innovation system in future researches is a good scope for other researchers to study.

\section{Conclusion}

In this study, an assessment of the BRICS NISs was conducted based on a bias-corrected network DEA. The national innovation process of NIS was divided into two sub-processes: knowledge production process and knowledge commercialization process. In doing so, we have bridged the research gap in the existing literature that used to deal with the innovation system as a one process leading to misleading results.

The results showed that BRICS NISs suffer from low performance in commercializing their outputs of universities and research organizations. On the other hand, their performance in creating scientific and technical knowledge is good in comparison to other studied countries. We suggest that the reason behind this imbalance is the network system failure associated with weak institutions and high uncertainty in the economy. 
Moreover, based on the projection analysis and correlation matrix analysis of DEA results, we suggest that in order to improve the national innovation performance of the BRICS countries, they need to do the following measures:

A. Shrinking the investment in the KPP inputs and focusing on adopting new management methods that reduce the cost opportunity of investing in the $\mathrm{KCP}$.

B. Building enablers and bridging organizations with a good institutional framework is a prerequisite of an efficient and productive relationship between the main NIS's actors.

C. A strong presence of government as a coordinator and a rules-maker at the national level is needed in BRICS economies that have a long history and experience in central planning.

D. Economic openness, well-structured and equipped technology clusters and clear definition of intellectual property rights are decisive elements in stimulating national and foreign investment and building sound industrial policy. With these conditions, MNCs will have the incentive to launch innovation-related businesses in BRICS countries. Consequently, the local industry will be able to absorb advanced technology and practices through interactive learning.

E. Building an international science, technology and innovation (STI) collaboration framework among BRICS countries helps in: (A) accessing to advanced scientific and technical knowledge, (B) faster exchanging and transferring knowledge and practices, (3) developing human resources in the field of science and technology (Sokolov et al. 2019).

All the above measures are directed at improving the performance of the commercialization process of knowledge in BRICS economies in order to improve their NISs. However, we argue that building a good NIS does not necessarily mean improving the national economic and social conditions automatically, evidence from the Indian case support this argument. Technological developments must be translated into improvements in the standard of living of citizens and lead to building a free and open knowledge society, which is an important prerequisite for sustaining innovation-based economic growth. Finally, we suggest that studying the political economy of the innovation system in the future researches will provide more insights to the policymakers. So, they will be able to understand the interactions among the actors in the system and direct their innovation policies and strategies towards establishing highly synergetic relationships and more efficient innovative activities. 


\section{Declarations}

7.1. Availability of data and material: The datasets used during the current study are available from the corresponding author on reasonable request.

7.2. Competing Interest: The authors declare that they have no conflict of interest.

7.3. Funding: The authors received no financial support for the research, authorship, and/or publication of this article.

7.4. Authors' contributions: AI performed the DEA analysis of the BRICS countries and wrote all parts of the study. All authors read and approved the final manuscript.

7.5. Acknowledgements: Not applicable

\section{References}

Abbasi, F., Hajihoseini, H., \& Haukka, S. (2011). Use of virtual index for measuring efficiency of innovation systems: A cross-country study. International Journal of Technology Management \& Sustainable Development, 9(3), 195-212. https://doi.org/10.1386/tmsd.9.3.195_1

Afzal, M. N. I. (2014). An empirical investigation of the National Innovation System (NIS) using Data Envelopment Analysis (DEA) and the TOBIT model. International Review of Applied Economics, 28(4), 507-523. https://doi.org/10.1080/02692171.2014.896880

Allard, G., Martinez, C. A., \& Williams, C. (2012). Political instability, pro-business market reforms and their impacts on national systems of innovation. Research Policy, 41(3), 638-651. https://doi.org/10.1016/j.respol.2011.12.005

Alnafrah, I., Al Naimi, K., \& Ahmad, M. (2018). A comparative analysis of national innovation systems' structures and their developmental impacts (Evidences from BRICS countries). Economics and Environmental Management, 1(32), 13-20. https://doi.org/10.17586/2310-1172-2018-11-1-13-20

Alnafrah, Ibrahim. (2019). Dynamic structural comparison of BRICS national innovation systems based on machine learning techniques. International Journal of Technological Learning, Innovation and Development, 11(3), 265-290. https://doi.org/10.1504/IJTLID.2019.102681 
Alnafrah, Ibrahim, \& Zeno, B. (2019). A new comparative model for national innovation systems based on machine learning classification techniques. Innovation and Development. https://doi.org/10.1080/2157930x.2018.1564124

Altuntas, S., Dereli, T., \& Kusiak, A. (2016). Assessment of corporate innovation capability with a data-mining approach: industrial case studies. Computers \& Industrial Engineering, 102, 58-68. https://doi.org/10.1016/J.CIE.2016.10.018

Andersen, P. D., Andersen, A. D., Jensen, P. A., \& Rasmussen, B. (2014). Sectoral innovation system foresight in practice: Nordic facilities management foresight. Futures, 61. https://doi.org/10.1016/j.futures.2014.04.012

Banker, R. D., Charnes, A., \& Cooper, W. W. (1984). Some Models for Estimating Technical and Scale Inefficiencies in Data Envelopment Analysis. Management Science, 30(9), 1078-1092. https://doi.org/10.1287/mnsc.30.9.1078

Biryukova, O. V., \& Matiukhina, A. I. (2019). ICT Services Trade in the BRICS Countries: Special and Common Features. Journal of the Knowledge Economy, 10(3), 1080-1097. https://doi.org/10.1007/s13132-017-0517-6

Bogdanova, E. L., \& Alnafrah, I. (2018). National Innovation System and Its Role in Increasing GDP Per Capita (Evidence from Russia). Journal of Economic Regulation, 9(1), 033-039. https://doi.org/10.17835/20785429.2018.9.1.033-039

Brando Santana, N., Mariano, E. B., Camioto, F. de C., \& Rebelatto, D. A. do N. (2015). National innovative capacity as determinant in sustainable development: a comparison between the BRICS and G7 countries. International Journal of Innovation and Sustainable Development, 9(3/4), 384. https://doi.org/10.1504/IJISD.2015.071860

Cai, Y. (2011). Factors Affecting the Efficiency of the BRICSs' National Innovation Systems: A Comparative Study Based on Dea and Panel Data Analysis. SSRN Electronic Journal. https://doi.org/10.2139/ssrn.1974368

Cai, Y., \& Hanley, A. (2012). Building BRICS: 2-Stage DEA analysis of R\&amp;D Efficiency.

Carayannis, E. G., Goletsis, Y., \& Grigoroudis, E. (2015). Multi-level multi-stage efficiency measurement: the 
case of innovation systems. Operational Research, 15(2), 253-274. https://doi.org/10.1007/s12351-0150176-y

Carayannis, E. G., Grigoroudis, E., \& Goletsis, Y. (2016). A multilevel and multistage efficiency evaluation of innovation systems: A multiobjective DEA approach. Expert Systems with Applications, 62(15 November), 63-80. https://doi.org/10.1016/j.eswa.2016.06.017

Cassiolato, J. E., \& Vitorino, V. (2009). BRICS and development alternatives: Innovation systems and policies. BRICS and Development Alternatives: Innovation Systems and Policies. https://doi.org/10.7135/UPO9781843318149

Castellacci, F., \& Natera, J. M. (2013). The dynamics of national innovation systems: A panel cointegration analysis of the coevolution between innovative capability and absorptive capacity. Research Policy, 42(3), 579-594. https://doi.org/10.1016/j.respol.2012.10.006

Charnes, A., Cooper, W. ., Golany, B., Seiford, L., \& Stutz, J. (1985). Foundations of data envelopment analysis for Pareto-Koopmans efficient empirical production functions. Journal of Econometrics, 30(1-2), 91-107. https://doi.org/10.1016/0304-4076(85)90133-2

Charnes, A., Cooper, W. W., \& Rhodes, E. (1978). Measuring the efficiency of decision making units. European Journal of Operational Research, 2(6), 429-444. https://doi.org/10.1016/0377-2217(78)901388

Chen, C.-P., Hu, J.-L., \& Yang, C.-H. (2011). An international comparison of R\&D efficiency of multiple innovative outputs: The role of the national innovation system. Innovation, 13(3), 341-360. https://doi.org/10.5172/impp.2011.13.3.341

Chen, K., \& Guan, J. (2011). Mapping the innovation production process from accumulative advantage to economic outcomes: A path modeling approach. Technovation. https://doi.org/10.1016/j.technovation.2011.03.004

Chen, K., \& Guan, J. (2012). Measuring the Efficiency of China’s Regional Innovation Systems: Application of Network Data Envelopment Analysis (DEA). Regional Studies, 46(3), 355-377. https://doi.org/10.1080/00343404.2010.497479

Chen, K., Kou, M., \& Fu, X. (2018). Evaluation of multi-period regional R\&amp;D efficiency: An application 
of dynamic DEA to China's regional R\&amp;D systems. Omega, 74, 103-114.

https://doi.org/10.1016/J.OMEGA.2017.01.010

Chen, Y., Cook, W. D., Li, N., \& Zhu, J. (2009). Additive efficiency decomposition in two-stage DEA. European Journal of Operational Research. https://doi.org/10.1016/j.ejor.2008.05.011

Chung, S. (2002). Building a national innovation system through regional innovation systems. Technovation, 22(8), 485-491. https://doi.org/10.1016/S0166-4972(01)00035-9

Cook, W. D., Liang, L., \& Zhu, J. (2010). Measuring performance of two-stage network structures by DEA: A review and future perspective. Omega, 38(6), 423-430. https://doi.org/10.1016/J.OMEGA.2009.12.001

Cooper, W. W., Seiford, L. M., \& Tone, K. (2006). Introduction to data envelopment analysis and its uses: With DEA-solver software and references. Introduction to Data Envelopment Analysis and Its Uses: With DEASolver Software and References. https://doi.org/10.1007/0-387-29122-9

Crespo, N. F., \& Crespo, C. F. (2016). Global innovation index: Moving beyond the absolute value of ranking with a fuzzy-set analysis. Journal of Business Research, 69(11), 5265-5271. https://doi.org/10.1016/J.JBUSRES.2016.04.123

Cron, W. L., \& Sobol, M. G. (1983). The relationship between computerization and performance: A strategy for maximizing the economic benefits of computerization. Information \& Management, 6(3), 171-181. https://doi.org/10.1016/0378-7206(83)90034-4

Didenko, A., Loseva, O., \& Abdikeev, N. (2017). Measuring Efficiency of Regional Innovation System with DEA and PCA. In 2017 IEEE 11th International Conference on Application of Information and Communication Technologies (AICT) (pp. 1-4). IEEE. https://doi.org/10.1109/ICAICT.2017.8687279

Distefano, F., Gambillara, G., \& Di Minin, A. (2016). Extending the Innovation Paradigm: a Double 'I' Environment and Some Evidence from BRIC Countries. Journal of the Knowledge Economy, 7(1), 126154. https://doi.org/10.1007/s13132-015-0299-7

Edquist, C. (2009). Systems of Innovation: Perspectives and Challenges. In The Oxford Handbook of Innovation. https://doi.org/10.1093/oxfordhb/9780199286805.003.0007

Emrouznejad, A., \& Yang, G. (2018). A survey and analysis of the first 40 years of scholarly literature in DEA: 1978-2016. Socio-Economic Planning Sciences, 61, 4-8. https://doi.org/10.1016/J.SEPS.2017.01.008 
Fagerberg, J., Mowery, D. C., \& Verspagen, B. (2009). The evolution of Norway's national innovation system. Science and Public Policy. https://doi.org/10.3152/030234209X460944

Färe, R., \& Grosskopf, S. (2000). Network DEA. Socio-Economic Planning Sciences, 34(1), 35-49. https://doi.org/10.1016/S0038-0121(99)00012-9

Filippetti, A., \& Peyrache, A. (2011). The Patterns of Technological Capabilities of Countries: A Dual Approach using Composite Indicators and Data Envelopment Analysis. World Development, 39(7), 11081121. https://doi.org/10.1016/J.WORLDDEV.2010.12.009

Freeman, C. (1982). The economics of industrial innovation. MIT Press.

Freeman, C., \& Lundvall, B.-A. (1988). Small countries facing the technological revolution. Pinter. https://vbn.aau.dk/en/publications/small-countries-facing-the-technological-revolution. Accessed 9 August 2019

Furman, J. L., Porter, M. E., \& Stern, S. (2002). The determinants of national innovative capacity. Research Policy, 31(6), 899-933. https://doi.org/10.1016/S0048-7333(01)00152-4

Gao, X., \& Yuan, J. (2020). Policymaking challenges in complex systems: The political and socio-technical dynamics of solar photovoltaic technology deployment in China. Energy Research and Social Science, 64. https://doi.org/10.1016/j.erss.2020.101426

Godin, B. (2009). National Innovation System: The System Approach in Historical Perspective. Science, Technology, \& Human Values. Sage Publications, Inc. https://doi.org/10.2307/27786171

Golany, B., \& Roll, Y. (1989). An application procedure for DEA. Omega, 17(3), 237-250. https://doi.org/10.1016/0305-0483(89)90029-7

Grupp, H., \& Schubert, T. (2010). Review and new evidence on composite innovation indicators for evaluating national performance. Research Policy. https://doi.org/10.1016/j.respol.2009.10.002

Guan, J., \& Chen, K. (2010). Measuring the innovation production process: A cross-region empirical study of China's high-tech innovations. Technovation, 30(5-6), 348-358. https://doi.org/10.1016/j.technovation.2010.02.001

Guan, J., \& Chen, K. (2012). Modeling the relative efficiency of national innovation systems. Research Policy, 41(1), 102-115. https://doi.org/10.1016/j.respol.2011.07.001 
Hekkert, M. P., Suurs, R. A. A., Negro, S. O., Kuhlmann, S., \& Smits, R. E. H. M. (2007). Functions of innovation systems: A new approach for analysing technological change. Technological Forecasting and Social Change, 74(4), 413-432. https://doi.org/10.1016/J.TECHFORE.2006.03.002

Huang, W., \& Eling, M. (2013). An efficiency comparison of the non-life insurance industry in the BRIC countries. European Journal of Operational Research. https://doi.org/10.1016/j.ejor.2012.11.008

Hudec, O., \& Prochádzková, M. (2013). The relative efficiency of knowledge innovation processes in EU countries. Studies in Regional Science, 41(1), 145-162. https://doi.org/10.2457/srs.43.145

Ivanova, I., Strand, Ø., Kushnir, D., \& Leydesdorff, L. (2017). Economic and technological complexity: A model study of indicators of knowledge-based innovation systems. Technological Forecasting and Social Change, 120(July 2017), 77-89. https://doi.org/10.1016/j.techfore.2017.04.007

Jiménez-Sáez, F., Zabala-Iturriagagoitia, J. M., Zofío, J. L., \& Castro-Martínez, E. (2011). Evaluating research efficiency within National R\&amp;D Programmes. Research Policy, 40(2), 230-241. https://doi.org/10.1016/J.RESPOL.2010.10.005

Kao, C. (2014). Network data envelopment analysis: A review. European Journal of Operational Research, 239(1), 1-16. https://doi.org/10.1016/J.EJOR.2014.02.039

Kao, C., \& Hwang, S.-N. (2008). Efficiency decomposition in two-stage data envelopment analysis: An application to non-life insurance companies in Taiwan. European Journal of Operational Research, 185(1), 418-429. https://doi.org/10.1016/J.EJOR.2006.11.041

Kao, C., \& Hwang, S.-N. (2010). Efficiency measurement for network systems: IT impact on firm performance. Decision Support Systems, 48(3), 437-446. https://doi.org/10.1016/j.dss.2009.06.002

Klein Woolthuis, R., Lankhuizen, M., \& Gilsing, V. (2005). A system failure framework for innovation policy design. Technovation, 25(6), 609-619. https://doi.org/10.1016/J.TECHNOVATION.2003.11.002

Kneip, A., Simar, L., \& Wilson, P. W. (2011). A Computationally Efficient, Consistent Bootstrap for Inference with Non-parametric DEA Estimators. Computational Economics, 38(4), 483-515. https://doi.org/10.1007/s10614-010-9217-z

Kou, M., Chen, K., Wang, S., \& Shao, Y. (2016). Measuring efficiencies of multi-period and multi-division systems associated with DEA: An application to OECD countries' national innovation systems. Expert 
Systems with Applications, 46, 494-510. https://doi.org/10.1016/J.ESWA.2015.10.032

Krasikova, T. Y., \& Ognev, D. V. (2014). Corruption as a negative factor affecting the development of university as a core in regional innovation system. Actual Problems of Economics, 161(11), 161-165.

Kravtsova, V., \& Radosevic, S. (2012). Are systems of innovation in Eastern Europe efficient? Economic Systems, 36(1), 109-126. https://doi.org/10.1016/J.ECOSYS.2011.04.005

Lee, H.-Y., \& Park, Y.-T. (2005). An international comparison of R\&amp;D efficiency: DEA approach. Asian Journal of Technology Innovation, 13(2), 207-222. https://doi.org/10.1080/19761597.2005.9668614

Lengyel, B., \& Leydesdorff, L. (2011). Regional Innovation Systems in Hungary: The Failing Synergy at the National Level. Regional Studies. https://doi.org/10.1080/00343401003614274

Li, L., Dai, Q., Huang, H., \& Wang, S. (2016). Efficiency decomposition with shared inputs and outputs in twostage DEA. Journal of Systems Science and Systems Engineering, 25(1), 23-38. https://doi.org/10.1007/s11518-016-5298-0

Liou, D.-Y. (2009). Two-stage R\&amp;D efficiency evaluation from the perspective of national innovation system. In PICMET '09 - 2009 Portland International Conference on Management of Engineering \& Technology (pp. 180-186). IEEE. https://doi.org/10.1109/PICMET.2009.5262226

Liu, X., \& White, S. (2001). Comparing innovation systems: a framework and application to China's transitional context. Research Policy, 30(7), 1091-1114. https://doi.org/10.1016/S0048-7333(00)00132-3

Liu, Z., Chen, X., Chu, J., \& Zhu, Q. (2018). Industrial development environment and innovation efficiency of high-tech industry: analysis based on the framework of innovation systems. Technology Analysis \& Strategic Management, 30(4), 434-446. https://doi.org/10.1080/09537325.2017.1337092

Lobazova, O. F. (2019). Mentality as a factor of innovation and anti-corruption behavior in the social management system. International Journal of Innovative Technology and Exploring Engineering, 8(12), 4667-4672. https://doi.org/10.35940/ijitee.L3867.1081219

Lu, W.-M., Kweh, Q. L., \& Huang, C.-L. (2014). Intellectual capital and national innovation systems performance. Knowledge-Based Systems, 71. https://doi.org/10.1016/j.knosys.2014.08.001

Lundvall, B. Å. (2007). National innovation systems - Analytical concept and development tool. Industry and Innovation. https://doi.org/10.1080/13662710601130863 
Malerba, F. (2002). Sectoral systems of innovation and production. Research Policy (Vol. 31).

http://citeseerx.ist.psu.edu/viewdoc/download?doi=10.1.1.323.6486\&rep=rep1\&type=pdf. Accessed 27 August 2019

Matei, M. M., \& Aldea, A. (2012). Ranking National Innovation Systems According to their technical Efficiency. Procedia - Social and Behavioral Sciences, 62(24 October), 968-974. https://doi.org/10.1016/j.sbspro.2012.09.165

Meng, W., Hu, Z., \& Liu, W. (2006). Efficiency evaluation of basic research in China. Scientometrics, 69(1), 85-101. https://doi.org/10.1007/s11192-006-0140-y

Metcalfe, S., \& Ramlogan, R. (2008). Innovation systems and the competitive process in developing economies. The Quarterly Review of Economics and Finance, 48(2), 433-446. https://doi.org/10.1016/j.qref.2006.12.021

Miravitlles, P., Achcaoucaou, F., Núñez-Carballosa, A., Guitart-Tarrés, L., \& Cruz-Cazares, C. (2017). Are the BRIC countries overtaking intermediate countries in the race for international R\&amp;D? The case of Spain. Technology Analysis \& Strategic Management, 29(6), 672-686.

https://doi.org/10.1080/09537325.2016.1227063

Namazi, M., \& Mohammadi, E. (2018). Natural resource dependence and economic growth: A TOPSIS/DEA analysis of innovation efficiency. Resources Policy, 59, 544-552.

https://doi.org/10.1016/J.RESOURPOL.2018.09.015

Nasierowski, W., \& Arcelus, F. J. (2003). On the efficiency of national innovation systems. Socio-Economic Planning Sciences, 37(3), 215-234. https://doi.org/10.1016/S0038-0121(02)00046-0

Nelson, R. R. (1993). National Innovation Systems : a Comparative Analysis. Oxford University Press, USA.

Pan, T.-W., Hung, S.-W., \& Lu, W.-M. (2010). DEA Performance Measurement Of The National Innovation System In Asia And Europe. Asia-Pacific Journal of Operational Research, 27(03), 369-392. https://doi.org/10.1142/S0217595910002752

Papaioannou, T., Watkins, A., Mugwagwa, J., \& Kale, D. (2016). To Lobby or to Partner? Investigating the Shifting Political Strategies of Biopharmaceutical Industry Associations in Innovation Systems of South Africa and India. World Development, 78, 66-79. https://doi.org/10.1016/j.worlddev.2015.10.017 
Pertuze Salas, J., Reyes, T., Vassolo, R. S., \& Olivares, N. (2019). Political uncertainty and innovation: The relative effects of national leaders' education levels and regime systems on firm-level patent applications. Research Policy, 48(9). https://doi.org/10.1016/j.respol.2019.103808

Pires, J. O., \& Garcia, F. (2012). Productivity of Nations: A Stochastic Frontier Approach to TFP Decomposition. Economics Research International, 2012, 1-19. https://doi.org/10.1155/2012/584869

Proksch, D., Haberstroh, M. M., \& Pinkwart, A. (2017). Increasing the national innovative capacity: Identifying the pathways to success using a comparative method. Technological Forecasting and Social Change, 116(March), 256-270. https://doi.org/10.1016/j.techfore.2016.10.009

Ramanathan, R., Ramanathan, U., \& Bentley, Y. (2018). The debate on flexibility of environmental regulations, innovation capabilities and financial performance - A novel use of DEA. Omega, 75, 131-138. https://doi.org/10.1016/J.OMEGA.2017.02.006

Rao-Nicholson, R., Vorley, T., \& Khan, Z. (2017). Social innovation in emerging economies: A national systems of innovation based approach. Technological Forecasting and Social Change, 121, 228-237. https://doi.org/10.1016/j.techfore.2017.03.013

Rousseau, S., \& Rousseau, R. (1997). Data envelopment analysis as a tool for constructing scientometric indicators. Scientometrics, 40(1), 45-56. https://doi.org/10.1007/BF02459261

Samara, E., Georgiadis, P., \& Bakouros, I. (2012). The impact of innovation policies on the performance of national innovation systems: A system dynamics analysis. Technovation, 32(11), 624-638. https://doi.org/10.1016/J.TECHNOVATION.2012.06.002

Scerri, M., \& Lastres, H. M. (2013). The State and the Architecture of National Systems of Innovation. In M. Scerri \& H. M. M. Lastres (Eds.), The Role of the State (pp. 1-21). Routledge India.

Scerri, M., Clara Couto Soares, M., \& Maharajh, R. (2010). Comparative Report on Innovation Systems and Inequality in the BRICS. From the research project: National Innovation Systems of BRICS countries. (IDRC Center file 104227-001). Rio de Janeiro.

Sesay, B., Yulin, Z., \& Wang, F. (2018). Does the national innovation system spur economic growth in Brazil, Russia, India, China and South Africa economies? Evidence from panel data. South African Journal of Economic and Management Sciences, 21(1), 1-12. https://doi.org/10.4102/sajems.v21i1.1647 
Sharma, S., \& Thomas, V. J. (2008). Inter-country R\&D efficiency analysis: An application of data envelopment analysis. Scientometrics, 76(3), 483-501. https://doi.org/10.1007/s11192-007-1896-4

Sokolov, A., Shashnov, S., Kotsemir, M., \& Grebenyuk, A. (2019). Quantitative analysis for a better-focused international STI collaboration policy: A case of BRICS. Technological Forecasting and Social Change, 147, 221-242. https://doi.org/10.1016/J.TECHFORE.2019.07.008

Song, M. L., Zhang, L. L., Liu, W., \& Fisher, R. (2013). Bootstrap-DEA analysis of BRICS' energy efficiency based on small sample data. Applied Energy. https://doi.org/10.1016/j.apenergy.2013.02.064

Tarnawska, K., \& Mavroeidis, V. (2015). Efficiency of the knowledge triangle policy in the EU member states: DEA approach. Triple Helix, 2(1), 1-22. https://doi.org/10.1186/s40604-015-0028-z

Tseng, C.-Y. (2009). Technological Innovation in The Bric Economies. Research-Technology Management, 52(2), 29-35. https://doi.org/10.1080/08956308.2009.11657556

Tu, C. J., Chang, M. C., \& Chen, C. P. (2016). Progressive time-weighted dynamic energy efficiency, energy decoupling rate, and decarbonization: An empirical study on G7 and BRICS. Sustainability (Switzerland). https://doi.org/10.3390/su8090928

Viotti, E. B. (2002). National Learning Systems: A new approach on technological change in late industrializing economies and evidences from the cases of Brazil and South Korea. Technological Forecasting and Social Change, 69(7), 653-680. https://doi.org/10.1016/S0040-1625(01)00167-6

Wang, C. H., Gopal, R. D., \& Zionts, S. (1997). Use of Data Envelopment Analysis in assessing Information Technology impact on firm performance. Annals of Operations Research, 73(0), 191-213. https://doi.org/10.1023/A:1018977111455

Wang, D., Zhao, X., \& Zhang, Z. (2016). The Time Lags Effects of Innovation Input on Output in National Innovation Systems: The Case of China. Discrete Dynamics in Nature and Society, 2016, 1-12. https://doi.org/10.1155/2016/1963815

Wang, E. C., \& Huang, W. (2007). Relative efficiency of R\&D activities: A cross-country study accounting for environmental factors in the DEA approach. Research Policy, 36(2), 260-273. https://doi.org/10.1016/J.RESPOL.2006.11.004

Wang, S., Fan, J., Zhao, D., \& Wang, S. (2016). Regional innovation environment and innovation efficiency: 
the Chinese case. Technology Analysis \& Strategic Management, 28(4), 396-410.

https://doi.org/10.1080/09537325.2015.1095291

Wang, Y.-M., \& Chin, K.-S. (2010). Some alternative DEA models for two-stage process. Expert Systems with Applications, 37(12), 8799-8808. https://doi.org/10.1016/J.ESWA.2010.06.024

Wang, Y., \& Li-Ying, J. (2014). How do the BRIC countries play their roles in the global innovation arena? A study based on USPTO patents during 1990-2009. Scientometrics, 98(2), 1065-1083.

https://doi.org/10.1007/s11192-013-1141-2

Watkins, A., Papaioannou, T., Mugwagwa, J., \& Kale, D. (2015). National innovation systems and the intermediary role of industry associations in building institutional capacities for innovation in developing countries: A critical review of the literature. Research Policy. https://doi.org/10.1016/j.respol.2015.05.004

Yao, X., Watanabe, C., \& Li, Y. (2009). Institutional structure of sustainable development in BRICs: Focusing on ICT utilization. Technology in Society, 31(1), 9-28. https://doi.org/10.1016/J.TECHSOC.2008.10.013

Zabala-Iturriagagoitia, J. M., Voigt, P., Gutiérrez-Gracia, A., \& Jiménez-Sáez, F. (2007). Regional Innovation Systems: How to Assess Performance. Regional Studies, 41(5), 661-672. https://doi.org/10.1080/00343400601120270

Zaichenko, S. (n.d.). National Innovation System and Inequality in Russia. In Inequality and Development Challenges (pp. 80-148). Routledge India. https://doi.org/10.4324/9781315734170-3

Zhao, S. L., Cacciolatti, L., Lee, S. H., \& Song, W. (2015). Regional collaborations and indigenous innovation capabilities in China: A multivariate method for the analysis of regional innovation systems.

Technological Forecasting and Social Change, 94(May), 202-220.

https://doi.org/10.1016/j.techfore.2014.09.014 


\section{Appendix A}

\section{Table 1. Descriptive Statistics}

\begin{tabular}{|c|c|c|c|c|c|}
\hline Variable & Description & Data source & Type & $\begin{array}{c}\text { Mean (all studied } \\
\text { countries) }\end{array}$ & Std. Deviation \\
\hline $\begin{array}{l}\text { R\&D financed by } \\
\text { Government (in } 2000 \\
\text { current PPP\$) }\end{array}$ & $\begin{array}{l}\text { R\&D financed by Government refers to the } \\
\text { financial resources that government allocates to } \\
\text { support research and development activities. }\end{array}$ & $\begin{array}{l}\text { UNESCO } \\
\text { Institute for } \\
\text { statistics }\end{array}$ & Input (KPP) & 8544208.14 & 15600025.48 \\
\hline Researchers total & $\begin{array}{l}\text { The number of researchers engaged in Research } \\
\text { \&Development (R\&D). Researchers are } \\
\text { professionals who conduct research and improve } \\
\text { or develop concepts, theories, models techniques } \\
\text { instrumentation, software of operational methods. } \\
\text { R\&D covers basic research, applied research, and } \\
\text { experimental development. }\end{array}$ & $\begin{array}{l}\text { UNESCO } \\
\text { Institute for } \\
\text { statistics and } \\
\text { World Bank }\end{array}$ & Input (KPP) & 8405643 & 13166765 \\
\hline $\begin{array}{l}\text { GERD - performed by } \\
\text { higher education (in } \\
2000 \text { current PPP\$) }\end{array}$ & $\begin{array}{l}\text { GERD - performed by higher education refers to } \\
\text { the financial resources that organizations of the } \\
\text { education system allocate to conduct research and } \\
\text { development activities. }\end{array}$ & $\begin{array}{l}\text { UNESCO } \\
\text { Institute for } \\
\text { statistics and } \\
\text { World Bank }\end{array}$ & Input (KPP) & 241187.52 & 380647.31 \\
\hline
\end{tabular}




\begin{tabular}{|c|c|c|c|c|c|}
\hline $\begin{array}{l}\text { Number of scientific and } \\
\text { technical journal articles } \\
\text { published }\end{array}$ & $\begin{array}{l}\text { Scientific and technical journal articles refer to } \\
\text { the number of scientific and engineering articles } \\
\text { published in the following fields: physics, } \\
\text { biology, chemistry, mathematics, clinical } \\
\text { medicine, biomedical research. }\end{array}$ & World Bank & $\begin{array}{c}\text { Output } \\
(\mathrm{KPP}) / \\
\text { Input (KCP) }\end{array}$ & 72816.55 & 109070.63 \\
\hline $\begin{array}{c}\text { Patent applications } \\
\text { (Residents) }\end{array}$ & $\begin{array}{l}\text { Patent applications are worldwide patent } \\
\text { applications filed through the Patent Cooperation } \\
\text { Treaty procedure or with a national patent office } \\
\text { for exclusive rights for an invention. }\end{array}$ & WIPO & $\begin{array}{c}\text { Output } \\
(\mathrm{KPP}) / \\
\text { Input (KCP) }\end{array}$ & 63533.04 & 199123.66 \\
\hline $\begin{array}{l}\text { GERD - performed by } \\
\text { business enterprise (in } \\
2000 \text { current PPP\$) }\end{array}$ & $\begin{array}{l}\text { GERD - performed by business enterprise refers } \\
\text { to the financial resources that business sector } \\
\text { allocates to conduct research and development } \\
\text { activities. }\end{array}$ & $\begin{array}{l}\text { UNESCO } \\
\text { Institute for } \\
\text { statistics }\end{array}$ & $\begin{array}{c}\text { Input }(\mathrm{KCP}) \\
\text { Intermediate }\end{array}$ & 41777881.65 & 90936904.5 \\
\hline $\begin{array}{l}\text { High-technology exports } \\
\text { (in current US\$) }\end{array}$ & $\begin{array}{l}\text { High-technology exports are products with high } \\
\text { R\&D intensity, such as in aerospace, computers, } \\
\text { pharmaceuticals, scientific instruments, and } \\
\text { electrical machinery. }\end{array}$ & World Bank & $\begin{array}{l}\text { Output } \\
\text { (KCP) / } \\
\text { Output } \\
\text { (Total) }\end{array}$ & 657979280133.28 & 754871364036.5 \\
\hline
\end{tabular}




\begin{tabular}{|l|l|c|c|c|}
\hline Trademark applications & Trademark applications filed are applications to & WIPO & Output & (KCP) / \\
& register a trademark with a national or regional & & Output \\
Intellectual Property (IP) office. & & (Total) & \\
\hline
\end{tabular}

\section{Table 2. NIS-related DEA studies}

\begin{tabular}{|c|c|c|}
\hline Article & Method & Variables \\
\hline $\begin{array}{c}\text { (Matei and Aldea } \\
\text { 2012) }\end{array}$ & $\begin{array}{l}\text { DEA } \\
\text { Innovation leaders; } \\
\text { Innovation followers; } \\
\text { Moderate innovators; } \\
\text { Modest innovators }\end{array}$ & $\begin{array}{l}\text { Input variables } \\
\text { New doctorate graduates (ISCED 6) per } 1000 \text { population aged 25-34; International scientific co-publications per } \\
\text { million population; Public R\&D expenditures as \% of GDP; Business R\&D expenditures as \% of GDP; PCT } \\
\text { patents applications per billion GDP; Community trademarks per billion GDP } \\
\text { Output variables } \\
\text { Employment in knowledge-intensive activities (manufacturing and services) as \% of total employment; Medium } \\
\text { and high-tech product exports as \% total product exports; Knowledge-intensive services exports as \% total service } \\
\text { exports. }\end{array}$ \\
\hline $\begin{array}{c}\text { (Guan and Chen } \\
\text { 2010) }\end{array}$ & $\begin{array}{l}\text { CRS- output oriented Two } \\
\text { stages DEA process }\end{array}$ & $\begin{array}{l}\text { Input (1) } \\
\text { R\&D expenditure; Number of scientists and researchers } \\
\text { Output (1) }\end{array}$ \\
\hline
\end{tabular}




\begin{tabular}{|c|c|c|}
\hline & & $\begin{array}{l}\text { Patent } \\
\text { Input (2) } \\
\text { Technology import } \\
\text { Output (2) } \\
\text { High-tech export }\end{array}$ \\
\hline (Samara et al. 2012) & $\begin{array}{l}\text { The paper analyses the } \\
\text { impact of innovation } \\
\text { Policies on the NIS } \\
\text { performance based on } \\
\text { system dynamics (SD) }\end{array}$ & $\begin{array}{l}\text { Public Expenditure on R\&D; Private Expenditures on R\&D; Patent; Trademark; Total public education } \\
\text { expenditure; Population with tertiary education per } 100 \text { population aged; doctorate graduates per } 1000 \text { population } \\
\text { aged; Government debt (\% GDP); Total tax rate; Number of procedures required to start a business; venture } \\
\text { capital; Employment in knowledge intensive services (\% of workforce). }\end{array}$ \\
\hline (Ivanova et al. 2017) & $\begin{array}{l}\text { Economic complexity } \\
\text { index; Patent complexity } \\
\text { index; Triple-helix } \\
\text { complexity index }\end{array}$ & Patent and groups of products. \\
\hline (Altuntas et al. 2016) & $\begin{array}{l}\text { A fuzzy-logic based data- } \\
\text { mining approach to assess } \\
\text { innovation capability of } \\
\text { manufacturing systems }\end{array}$ & - \\
\hline
\end{tabular}




\begin{tabular}{|c|c|c|}
\hline (Lee and Park 2005) & $\begin{array}{l}\text { DEA } \\
\text { The output oriented CCR } \\
\text { model } \\
\text { Clustering } \\
+ \\
\text { Anova - ANOVA and Post- } \\
\text { hoc Comparisons } \\
\text { inventors, merchandisers, } \\
\text { academicians, and duds }\end{array}$ & $\begin{array}{l}\text { Input } \\
\text { R\&D expenditure: Average R\&D expenditure of a country for the period 1994-1998, Researchers: Average } \\
\text { number of researchers of a country for the period 1994-1998 } \\
\text { Output } \\
\text { Technology balance of receipts in 1999, Number of scientific and technical journal articles published in 1999, } \\
\text { Number of triadic patent families in } 1999\end{array}$ \\
\hline $\begin{array}{l}\text { (Guan and Chen } \\
\text { 2012) }\end{array}$ & $\begin{array}{l}\text { DEA } \\
\text { CRS and VRS, Network } \\
\text { (2-stage)-output } \\
\text { oriented Super } \\
\text { efficiency } \\
\text { Tobit regression on } \\
\text { environmental factors }\end{array}$ & $\begin{array}{l}\text { Inputs } \\
\text { Number of full-time equivalent scientists and engineers, Incremental R\&D expenditure funding; innovation } \\
\text { activities; Prior accumulated knowledge stock breeding upstream knowledge production; consumed full-time } \\
\text { equivalent labor for non-R\&D activities; number of patents granted (intermediate) } \\
\text { Outputs } \\
\text { Number of patents granted (intermediate); International scientific papers; added value of industries; Export of new } \\
\text { products in high-tech industries. }\end{array}$ \\
\hline (Lu et al. 2014) & Network DEA & Inputs \\
\hline
\end{tabular}




\begin{tabular}{|c|c|c|}
\hline & & $\begin{array}{l}\text { Total R\&D personnel; public expenditures on education; import of goods and commercial services; total } \\
\text { expenditures on R\&D. } \\
\qquad \text { Outputs } \\
\text { GDP; published scientific articles; patents (residents and nonresidents). }\end{array}$ \\
\hline $\begin{array}{c}\text { (Carayannis et al. } \\
\text { 2015) }\end{array}$ & $\begin{array}{l}\text { VRS-multistage, } \\
\text { multilevel ( } 2 \text { stages } \\
\text { x } 2 \text { levels) }\end{array}$ & $\begin{array}{l}\text { Inputs } \\
\text { Science graduates in tertiary education; Participation in lifelong learning; Total R\&D expenditure; R\&D capital } \\
\text { stock; Citable documents (intermediate); Patent applications (intermediate); Employment in knowledge intensive } \\
\text { services/manufacturing intermediate); SMEs collaborating with others intermediate); Venture capital investment } \\
\text { (intermediate). } \\
\text { Outputs } \\
\text { High Tech Exports; Sales of new to market and new to firm innovation; License and patent revenues from abroad; } \\
\text { Number of trademark applications in national offices. }\end{array}$ \\
\hline $\begin{array}{l}\text { (E. C. Wang and } \\
\text { Huang 2007) }\end{array}$ & $\begin{array}{l}\text { Three-stage approach } \\
\text { Input-oriented DEA - } \\
\text { BCC; Tobit regressions; } \\
\text { Parameter estimates from } \\
\text { the second stage are used to } \\
\text { predict the total input } \\
\text { slacks. }\end{array}$ & $\begin{array}{l}\text { Inputs } \\
\text { GERD; fixed capital formation; Researchers; Technicians. } \\
\text { Outputs } \\
\text { Patents by country; Patents by US; SCI Papers; EI Papers. }\end{array}$ \\
\hline
\end{tabular}




\begin{tabular}{|c|c|c|}
\hline $\begin{array}{l}\text { (C.-P. Chen et al. } \\
\text { 2011) }\end{array}$ & $\begin{array}{l}\text { DEA - output-oriented- } \\
\text { CRS }\end{array}$ & $\begin{array}{l}\text { Inputs } \\
\text { Total R\&D manpower (OECD indicator); R\&D expenditure stocks. } \\
\text { Outputs } \\
\text { Patents; Scientific journal articles; Royalty and licensing fees. }\end{array}$ \\
\hline (Pan et al. 2010) & Input- oriented DEA model & $\begin{array}{l}\text { Inputs } \\
\text { Total public expenditure on education; Imports of goods and commercial services; Total expenditure on R\&D; } \\
\text { Direct investment stocks abroad; Total R\&D personnel nationwide. } \\
\text { Outputs } \\
\text { Number of patents granted to residents; Number of patents secured abroad by national residents; Scientific articles } \\
\text { published by origin of author. }\end{array}$ \\
\hline $\begin{array}{l}\text { (Pires and Garcia } \\
\text { 2012) }\end{array}$ & $\begin{array}{l}\text { Stochastic Frontier } \\
\text { Analysis (SFA) } \\
\text { productivity analysis }\end{array}$ & $\begin{array}{l}\text { GDP growth; Capital accumulation; Labor expansion; Change in GDP per worker; R\&D expenditures; Average } \\
\text { years of schooling of population over } 25 \text { years. }\end{array}$ \\
\hline (Cai 2011) & DEA + OLS Regression & $\begin{array}{l}\text { Inputs } \\
\text { R\&D expenditure as a \% of GDP; Total R\&D personnel. } \\
\text { Output }\end{array}$ \\
\hline
\end{tabular}




\begin{tabular}{|c|c|c|}
\hline & & $\begin{array}{l}\text { Patents per } 1000 \text { population; Scientific articles per } 1000 \text { population; High-tech exports as a } \% \text { of total } \\
\text { manufacturing exports. }\end{array}$ \\
\hline (Afzal 2014) & $\begin{array}{l}\text { Output- oriented DEA- } \\
\text { CRS + Tobit regression } \\
\text { model }\end{array}$ & $\begin{array}{l}\text { Inputs } \\
\text { Population ages } 15 \text { to } 65 \text { ( } \% \text { of total) as labour force; Computer users per 1000; Domestic credit provided by } \\
\text { banking sector ( } \% \text { of GDP); R\&D expenditure \% GDP; School enrolment, secondary (\%gross); Cost of business } \\
\text { start-up procedure ( } \% \text { of GNI per capita); Regulatory quality; Openness (Trade (\% of GDP); Total natural } \\
\text { resources rents ( } \% \text { of GDP). } \\
\text { High-tech export as \% total manufacturing exports }\end{array}$ \\
\hline $\begin{array}{l}\text { (Zabala- } \\
\text { Iturriagagoitia et al. } \\
\text { 2007) }\end{array}$ & DEA & $\begin{array}{l}\text { Inputs } \\
\text { Property right; medium-tech industries; public R\&D expenditure R\&D; business R\&D expenditure; The } \\
\text { percentage of the population between } 25 \text { and } 64 \text { years of age with a higher education. } \\
\text { Outputs } \\
\text { Patents, GDP per capita }\end{array}$ \\
\hline (Kou et al. 2016) & $\begin{array}{l}\text { Multi-period and multi- } \\
\text { division systems } \\
\text { (MPMDS), Dynamic } \\
\text { network DEA (DN-DEA) }\end{array}$ & $\begin{array}{lc} & \text { Inputs } \\
\text { R\&D expenditure, R\&D personnel } & \\
& \text { Intermediate output } \\
\text { S\&T_papers } & \\
& \text { Intermediate Input }\end{array}$ \\
\hline
\end{tabular}




\begin{tabular}{|c|c|c|}
\hline & & $\begin{array}{l}\text { Technology import } \\
\qquad \text { Outputs } \\
\text { Export of high -tech products; GDP of employment (The ratio of gross domestic product (GDP) to total } \\
\text { employment in the economy.) }\end{array}$ \\
\hline $\begin{array}{l}\text { (Nasierowski and } \\
\text { Arcelus 2003) }\end{array}$ & $\begin{array}{l}\text { Two step- DEA (CCR) } \\
\text { input-orientation + PCA } \\
\text { (two principal components } \\
\text { analysis) }\end{array}$ & $\begin{array}{l}\text { Inputs } \\
\text { Imports of goods and commercial services; Gross domestic expenditure on research; Employment in R\&D; Total } \\
\text { educational expenditures. } \\
\text { Moderators } \\
\text { Country’s population; Gross domestic product; Purchasing power parity; Power distance; Uncertainty avoidance; } \\
\text { Masculinity; Individualism; Literacy rate. } \\
\text { External patents by resident; Patents by a country's residents; National productivity. }\end{array}$ \\
\hline (Proksch et al. 2017) & $\begin{array}{l}\text { Fuzzy-set qualitative } \\
\text { comparative analysis } \\
\text { (fsQCA) }\end{array}$ & $\begin{array}{l}\text { International patents per million inhabitants; GDP per capita; Stock of international patents; Aggregate employed } \\
\text { scientific and technological; Aggregate R\&D expenditures; Openness to international trade and venture capital; } \\
\text { Strength of protection for IP; Share of government expenditure on higher education; Stringency of antitrust } \\
\text { policies; Specialization degree; New business registered; Capital formation. }\end{array}$ \\
\hline (D. Wang et al. 2016) & $\begin{array}{l}\text { The time lags effects of } \\
\text { innovation input on output } \\
\text { in the NISs }\end{array}$ & $\begin{array}{l}\text { Researchers in R\&D (per million people), R\&D expenditure (\% of GDP), Regulatory quality, University-industry } \\
\text { research collaboration, Patent applications, residents }\end{array}$ \\
\hline
\end{tabular}




\begin{tabular}{|c|c|c|}
\hline $\begin{array}{l}\text { (Filippetti and } \\
\text { Peyrache 2011) }\end{array}$ & DEA and PCA & $\begin{array}{l}\text { Three dimensions } \\
\text { Business innovation } \\
\text { Triadic patents; Business R\&D (BERD). } \\
\text { Knowledge and skills } \\
\text { Total researchers in R\&D (FTE); Scientific and technical articles; Public R\&D; Higher Education Expenditure on } \\
\text { R\&D; Labor force with tertiary education. } \\
\text { Infrastructures } \\
\text { Personal computers; Fixed-line and mobile telephones; Internet users; Gross fixed capital formation; Broadband } \\
\text { subscribers. }\end{array}$ \\
\hline (Zhao et al. 2015) & $\begin{array}{l}\text { Ordinal Multidimensional } \\
\text { Scaling and Cluster } \\
\text { analysis }\end{array}$ & - \\
\hline (Sesay et al. 2018) & $\begin{array}{l}\text { Dynamic Panel Data } \\
\text { Analysis } \\
\text { NIS } \rightarrow \text { Economic Growth }\end{array}$ & $\begin{array}{l}\text { University enrolment rate for science and engineering students; government research and development } \\
\text { expenditure; high-tech export; total number of patents; scientific personnel; scientific and technical journal articles; } \\
\text { economic freedom. }\end{array}$ \\
\hline $\begin{array}{l}\text { (Crespo and Crespo } \\
\text { 2016) }\end{array}$ & $\begin{array}{l}\text { Fuzzy-set qualitative } \\
\text { comparative analysis }\end{array}$ & $\begin{array}{l}\text { Five input enablers of GII } \\
\text { Institutions; human capital and research; infrastructure; market sophistication; business sophistication. }\end{array}$ \\
\hline
\end{tabular}




\begin{tabular}{|l|l|l|}
\hline (Furman et al. 2002) & $\begin{array}{l}\text { Modeling national } \\
\text { innovative capacity based } \\
\text { on Romer formulation }\end{array}$ & $\begin{array}{l}\text { Inputs } \\
\text { Ratents, Patent per million; R\&D expenditure; Openness; Education expenditure; R\&D spending by privet sector; } \\
\end{array}$ \\
& Publications; GDP; Capital Stock; High-tech exports. \\
& \\
& \\
\end{tabular}




\begin{tabular}{|c|c|c|c|c|c|}
\hline & $\begin{array}{c}\text { R\&D } \\
\text { financed by } \\
\text { Government }\end{array}$ & $\begin{array}{c}\text { Researchers } \\
\text { total }\end{array}$ & $\begin{array}{l}\text { GERD - } \\
\text { performed } \\
\text { by higher } \\
\text { education }\end{array}$ & $\begin{array}{c}\text { Number of } \\
\text { scientific and } \\
\text { technical } \\
\text { journal } \\
\text { articles } \\
\text { published }\end{array}$ & $\begin{array}{c}\text { Patent } \\
\text { applications } \\
\text { (Residents) }\end{array}$ \\
\hline $\begin{array}{c}\text { R\&D financed by } \\
\text { Government }\end{array}$ & 1 & $.800^{* *}$ & $.966^{* *}$ & $.965^{* *}$ & $.829^{* *}$ \\
\hline Researchers total & $.800^{* *}$ & 1 & $.828^{* *}$ & $.882^{* *}$ & $.522^{* *}$ \\
\hline $\begin{array}{c}\text { GERD - performed by higher } \\
\text { education }\end{array}$ & $.966^{* *}$ & $.828^{* *}$ & 1 & $.978^{* *}$ & $.872^{* *}$ \\
\hline $\begin{array}{l}\text { Number of scientific and } \\
\text { technical journal articles } \\
\text { published }\end{array}$ & $.965^{* *}$ & $.882^{* *}$ & $.978^{* *}$ & 1 & $.824^{* *}$ \\
\hline $\begin{array}{l}\text { Patent applications } \\
\text { (Residents) }\end{array}$ & $.829^{* *}$ & $.522^{* * *}$ & $.872^{* *}$ & $.824^{* *}$ & 1 \\
\hline
\end{tabular}

${ }_{* * * *}^{* * *},{ }^{*}$ represent significance at 1,5 , and $10 \%$ level of significance, respectively.

Table 4. Correlations Matrix (KCP)

\begin{tabular}{|c|c|c|c|c|c|}
\hline & $\begin{array}{l}\text { Number of } \\
\text { scientific } \\
\text { and } \\
\text { technical } \\
\text { journal } \\
\text { articles } \\
\text { published }\end{array}$ & $\begin{array}{c}\text { Patent } \\
\text { applications } \\
\text { (Residents) }\end{array}$ & $\begin{array}{l}\text { GERD - } \\
\text { performed } \\
\text { by business } \\
\text { enterprise }\end{array}$ & $\begin{array}{l}\text { High- } \\
\text { technology } \\
\text { exports }\end{array}$ & $\begin{array}{l}\text { Trademark } \\
\text { applications }\end{array}$ \\
\hline $\begin{array}{c}\text { Number of scientific and } \\
\text { technical journal articles } \\
\text { published }\end{array}$ & 1 & $.824^{* *}$ & $.980^{* *}$ & $.928^{* *}$ & $.773^{* *}$ \\
\hline
\end{tabular}




\begin{tabular}{|c|c|c|c|c|c|}
\hline $\begin{array}{l}\text { Patent applications } \\
\text { (Residents) }\end{array}$ & $.824^{* *}$ & 1 & $.823^{* *}$ & $.719^{* *}$ & $.978^{* *}$ \\
\hline $\begin{array}{c}\text { GERD - performed by } \\
\text { business enterprise }\end{array}$ & $.980^{* *}$ & $.823^{* *}$ & 1 & $.930^{* *}$ & $.742^{* *}$ \\
\hline High-technology exports & $.928^{* *}$ & $.719^{* *}$ & $.930^{* * *}$ & 1 & $.640^{* *}$ \\
\hline Trademark applications & $.773^{* *}$ & $.978^{* *}$ & $.742^{* *}$ & $.640^{* *}$ & 1 \\
\hline
\end{tabular}

${ }^{* * *},{ }^{* *},{ }^{*}$ represent significance at 1,5 , and $10 \%$ level of significance, respectively.

Table 5. Correlations Matrix (Total)

\begin{tabular}{|c|c|c|c|c|c|}
\hline & $\begin{array}{l}\text { R\&D } \\
\text { financed by } \\
\text { Government }\end{array}$ & $\begin{array}{c}\text { Researchers } \\
\text { total }\end{array}$ & $\begin{array}{l}\text { GERD - } \\
\text { performed } \\
\text { by higher } \\
\text { education }\end{array}$ & $\begin{array}{l}\text { High- } \\
\text { technology } \\
\text { exports }\end{array}$ & $\begin{array}{l}\text { Trademark } \\
\text { applications }\end{array}$ \\
\hline $\begin{array}{l}\text { R\&D financed by } \\
\text { Government }\end{array}$ & 1 & $.800^{* *}$ & $.966^{* *}$ & $.879^{* *}$ & $.799^{* *}$ \\
\hline Researchers total & $.800^{* *}$ & 1 & $.828^{* *}$ & $.909^{* *}$ & $.415^{*}$ \\
\hline $\begin{array}{l}\text { GERD - performed by } \\
\text { higher education }\end{array}$ & $.966^{* *}$ & $.828^{* *}$ & 1 & $.906^{* *}$ & $.816^{* *}$ \\
\hline High-technology exports & $.879^{* *}$ & $.909^{* *}$ & $.906^{* *}$ & 1 & $.640^{* * *}$ \\
\hline Trademark applications & $.799^{* *}$ & $.415^{*}$ & $.816^{* *}$ & $.640^{* *}$ & 1 \\
\hline
\end{tabular}

${ }^{* * *},{ }^{* *},{ }^{*}$ represent significance at 1,5 , and $10 \%$ level of significance, respectively.

Table 6. RTS-Test of returns to scale

\begin{tabular}{|c|c|c|c|}
\hline \multirow{2}{*}{ Process } & Orientation & P - Value & Decision \\
\hline \multirow{2}{*}{ KPP } & Input & $0.001^{* * *}$ & Reject $\mathrm{H}_{0}$ \\
\cline { 2 - 4 } & Output & $0.05^{*}$ & Reject $\mathrm{H}_{0}$ \\
\hline \multirow{2}{*}{ KCP } & Input & $0.05^{*}$ & Reject $\mathrm{H}_{0}$ \\
\cline { 2 - 4 } & Output & $0.05^{*}$ & Reject $\mathrm{H}_{0}$ \\
\hline \multirow{2}{*}{ Total } & Input & $0.02^{* *}$ & Reject $\mathrm{H}_{0}$ \\
\hline & Output & $0.02^{* *}$ & Reject $\mathrm{H}_{0}$ \\
\hline
\end{tabular}

******, ${ }^{*}$ represent significance at 1,5 , and $10 \%$ level of significance, respectively. 
Table 9. Correlation matrix of total innovation performance with KPP\&KCP.

\begin{tabular}{|c|c|c|c|}
\hline & KPP efficiency score & KCP efficiency score & Total efficiency score \\
\hline KPP efficiency score & 1 & 0.105 & 0.337 \\
\hline KCP efficiency score & 0.105 & 1 & $0.590^{* *}$ \\
\hline Total efficiency score & 0.337 & $0.590^{* *}$ & 1 \\
\hline
\end{tabular}

${ }^{* * * *},{ }^{* *},{ }^{*}$ represent significance at 1,5 , and $10 \%$ level of significance, respectively. 
Figures

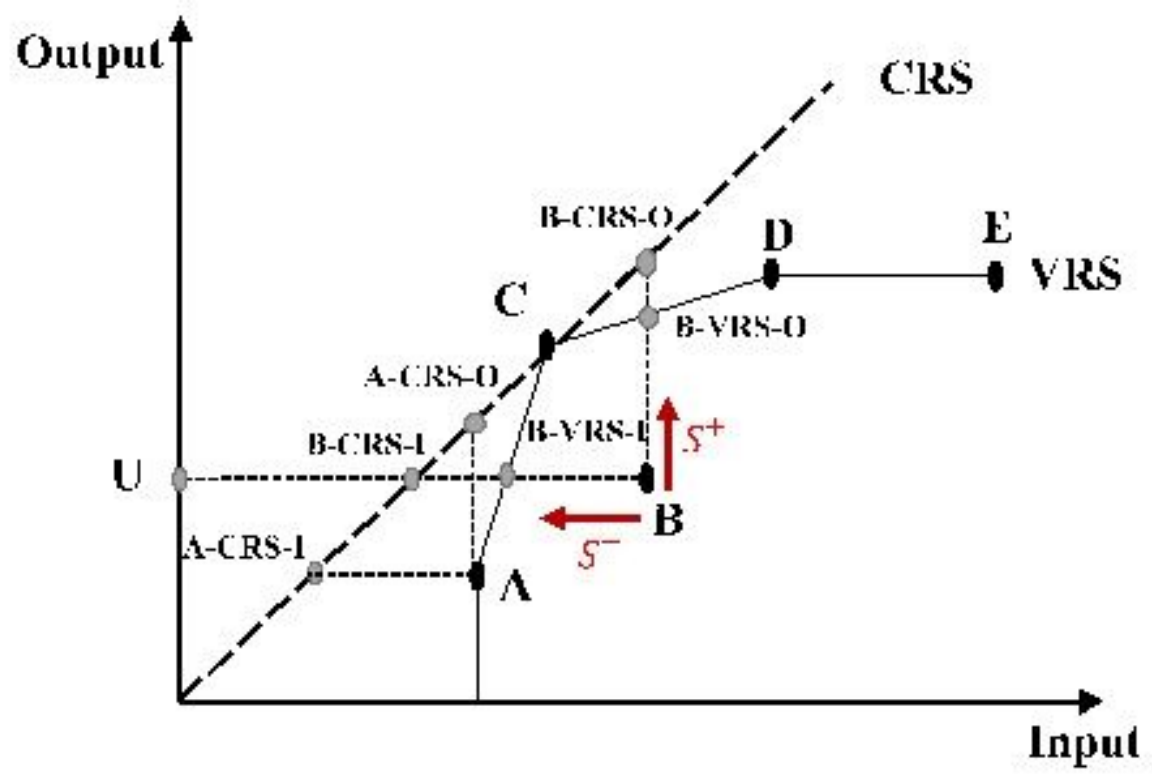

Figure 1

CRS and VRS DEA Models

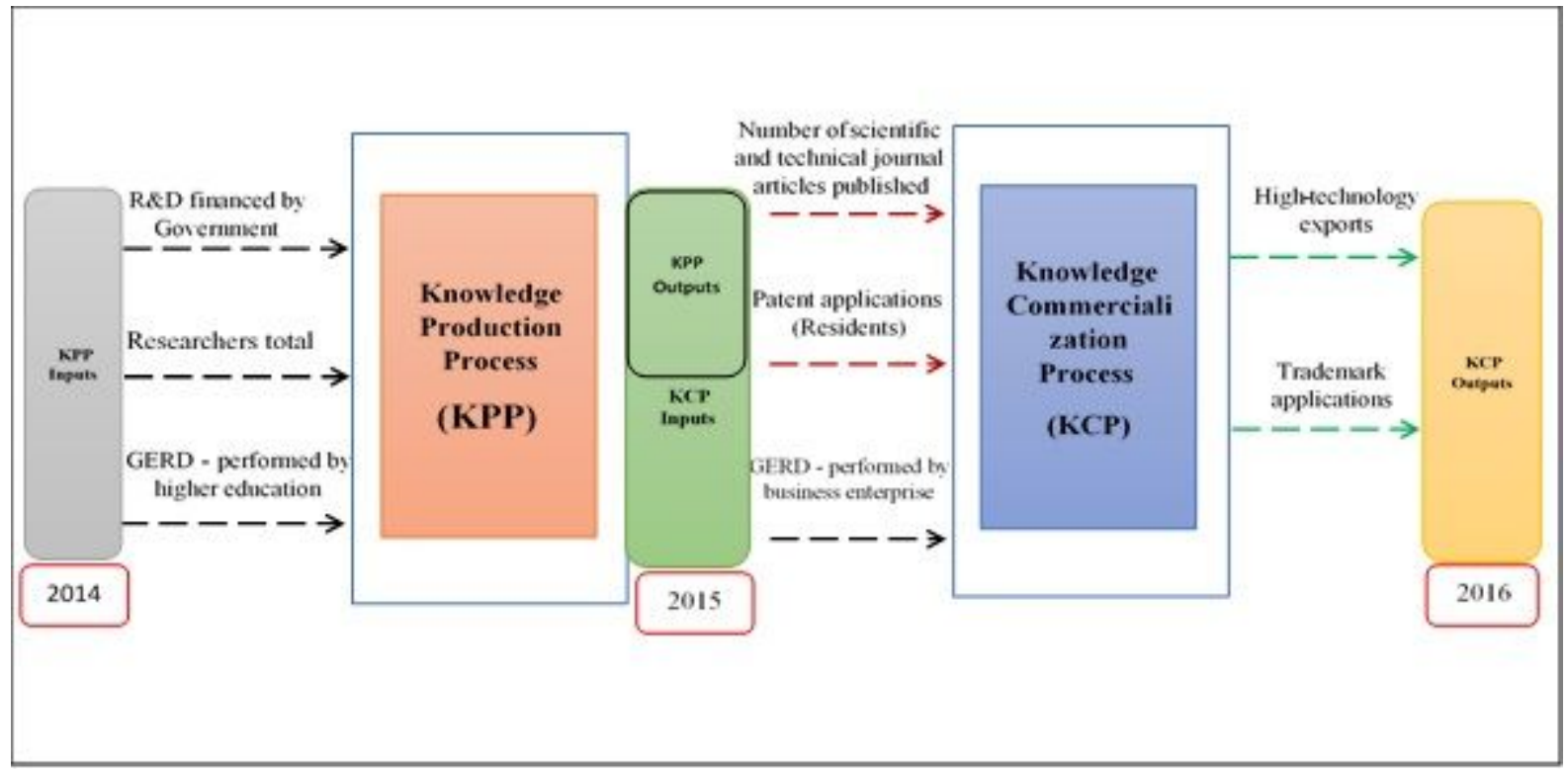

Figure 2

NIS's sub-processes 


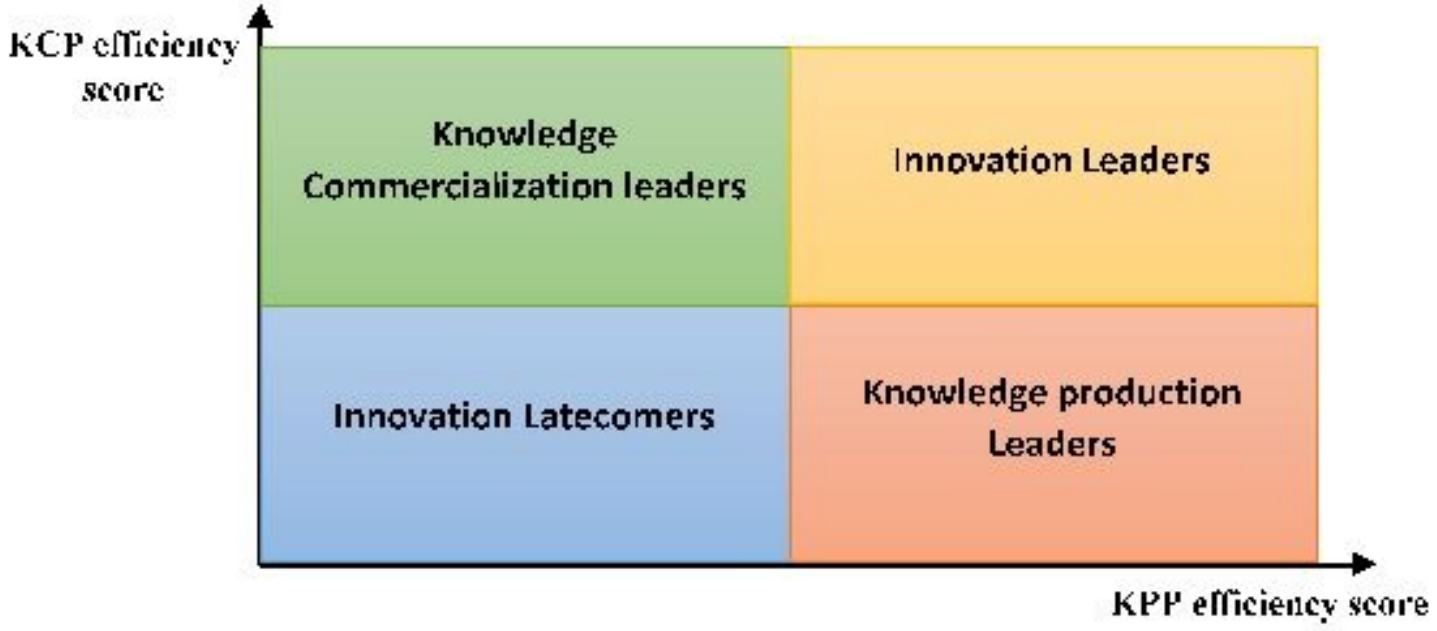

\section{Figure 3}

NISs Classification Matrix

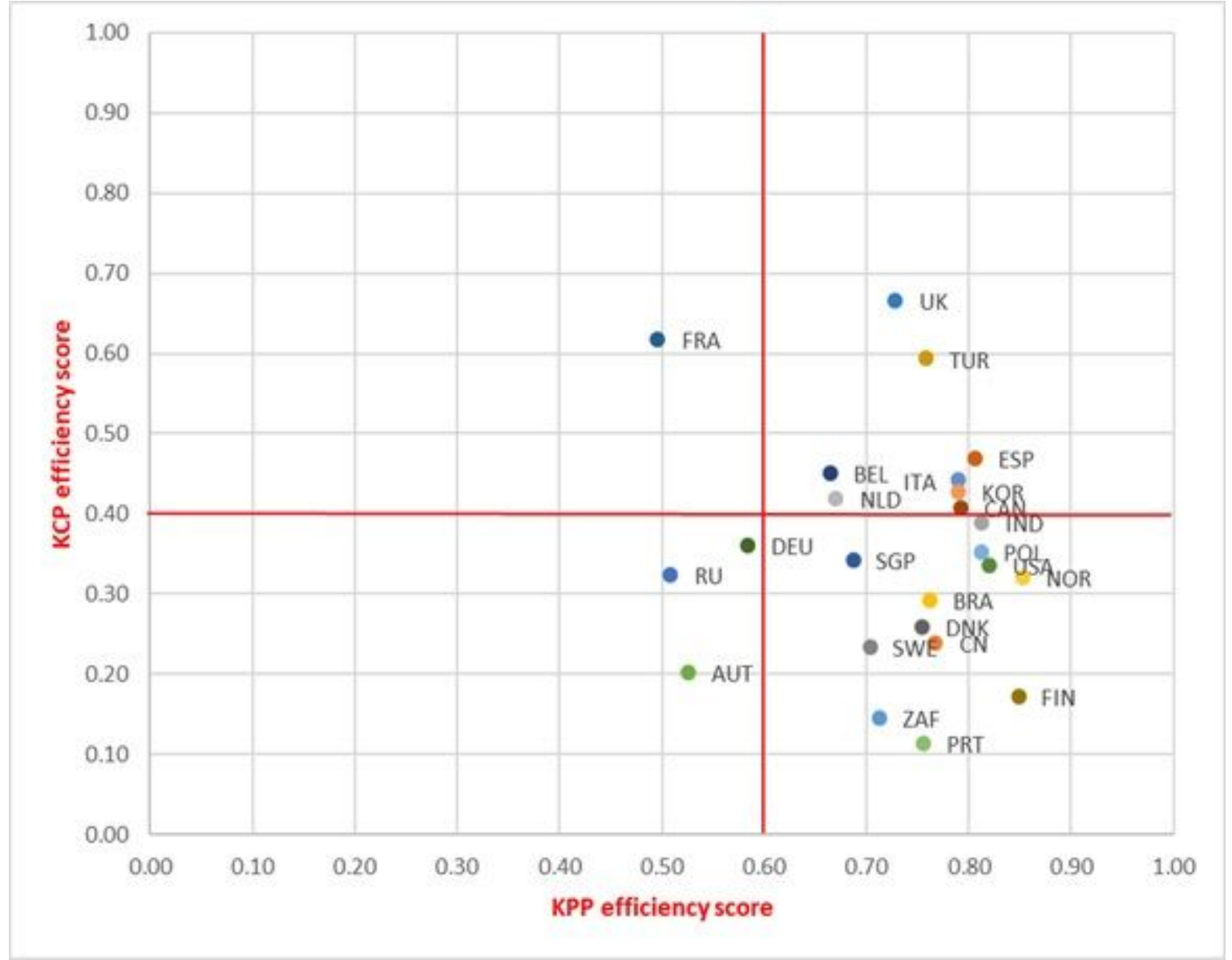

Figure 4

NISs classification based on DEA results 